\title{
NEW EVIDENCE FOR GRETACEOUS STRIKE-SLIP FAULTING IN THE UNITED STATES CORDILLERA AND IMPLICATIONS FOR TERRANE-DISPLACEMENT, DEFORMATION PATTERNS, AND PLUTONISM
}

\author{
SANDRA J. WYLD and JAMES E. WRIGHT \\ Department of Geology, University of Georgia, Athens, Georgia 30602
}

\begin{abstract}
Early to mid-Cretaceous dextral strike-slip faulting, involving up to 400 km displacement, has been documented in the southern Sierra Nevada of California. In western Idaho, the Salmon River suture juxtaposes unrelated oceanic and continental rocks along a major, near-vertical shear zone that was active in the Early to mid-Cretaceous. These two structural zones have been treated as separate entities; however, new data indicate that they likely connect via a structural discontinuity in northwest Nevada and southeast Oregon, herein called the western Nevada shear zone (WNS).

Current structures within the WNS record dip-slip contractional deformation; however, regional relations (structural and stratigraphic) indicate a mismatch in the early Mesozoic geology of rocks across the WNS that is best explained by dextral strike-slip displacement of several $100 \mathrm{~km}$. These relations argue that an early strike-slip structure along the WNS was reactivated and obscured during later regional shortening deformation, most likely related to the Cretaceous Sevier orogeny. The WNS is along strike and broadly coeval with the Salmon River suture zone and strike-slip boundaries in the Sierra Nevada. We hypothesize that all these features are related elements of a major structural boundary in the western United States Cordillera. This boundary is interpreted to have accommodated significant dextral strike-slip displacement of outboard arc terranes of the Cordillera in the Early Cretaceous, followed by reactivation as a localized contractional zone in the mid-Cretaceous during the Sevier orogeny. Cretaceous batholiths of the United States Cordillera closely parallel the boundary, which we suggest formed a major crustal flaw that localized and facilitated emplacement of arc magmas.
\end{abstract}

\section{INTRODUCTION}

Oblique subduction along convergent plate margins can lead to margin-parallel strike-slip faulting in the upper plate, particularly when the angle of obliquity is high, when there is strong coupling between the two plates (that is, when the two plates converge rapidly in an absolute reference frame and/or when the subduction dip angle is shallow), and when the upper plate is composed of continental crust (Dewey, 1980; Beck, 1983; Jarrard, 1986). Strike-slip faulting will typically occur within the arc region because here the lithosphere is thinnest and weakest due to high heat flow associated with arc magmatism. Long-lived convergent margins (active for many 10's of my) are likely to experience significant periods of this type of strike-slip faulting, because the probability that convergence over such long periods of time would be consistently orthogonal to the plate boundary is small (Jarrard, 1986).

A prime example of this type of margin is found in the western North American Cordillera. Here, subduction demonstrably occurred beneath the continent from at least the Triassic to the early Cenozoic (Burchfiel, Cowan, and Davis, 1992), and subduction-related upper plate strike-slip faulting is expected to have occurred during at least some parts of this time frame. Episodes of oblique plate convergence along this margin in the Jurassic and Cretaceous have been identified by plate motion reconstructions (Engebretson, Cox, and Gordon, 1985). The Cretaceous in particular is a time during which upper plate strike-slip faulting should be likely, for two additional reasons. First, shortening deformation in the Cordillera during the Jurassic closed marginal marine basins and resulted in accretion of outboard island arc terranes to the 
continent (Saleeby and Busby-Spera, 1992; Smith and others, 1993); as a consequence, the North American margin during the Cretaceous was composed of thickened crust that can be considered continental in rheology. Second, substantial shortening deformation continued in the Cordillera during the Cretaceous (Burchfiel, Cowan, and Davis, 1992), which indicates that this time frame was associated with strong plate coupling. As noted by Beck (1983) and Jarrard (1986), these factors would help to facilitate upper plate strike-slip faulting due to oblique plate convergence.

Geologic and paleomagnetic evidence for Cretaceous strike-slip faulting exists within the North American Cordillera and indicates dextral displacement of outboard terranes from a few tens to potentially thousands of kilometers. Much of this analysis has focused on relations in the Canadian and northern Washington parts of the Cordillera (Beck, 1976; Beck, Burmeister, and Schoonover, 1981; Gabrielse, 1985; Irving, 1985; Irving and Wynne, 1990; Irving and others 1996; Wynne and others, 1995; Bassett and Kleinspehn, 1996; Umhoefer and Schriarizza, 1996; Cowan, Brandon, and Garver, 1997; Hollister and Andronicos, 1997; Ward and others, 1997). Less is known about any Cretaceous strike-slip faulting and associated terrane translation in the Cordillera south of Washington state, where accretion of outboard terranes has more commonly been viewed in terms of "accordian" tectonics, involving displacements perpendicular to the margin. More recently, however, studies in the United States Cordillera are increasingly emphasizing the importance of Mesozoic strike-slip displacements (Harper, Saleeby, and Norman, 1985; Lund and Snee, 1988; Busby-Spera and Saleeby, 1990; Schweickert and Lahren, 1990; Saleeby and Busby-Spera, 1992; Oldow and others, 1989; Jayko and Blake, 1993; Greene and Schweickert, 1995; Wyld, Quinn, and Wright, 1996; Tikoff and de Saint Blanquat, 1997).

In this paper, we focus on new evidence for Cretaceous strike-slip faulting and terrane translation in the Cordillera south of Washington state; for brevity, we will simply refer to this part of the Cordillera as the United States Cordillera throughout the remainder of the paper. Our principal conclusions are: (1) New data from northwest Nevada and southeast Oregon indicate that this area contains a major tectonic (terrane) boundary; (2) Several lines of evidence suggest that this terrane boundary accommodated dextral strike-slip displacement in the Early Cretaceous; (3) Considered in conjunction with regional relations elsewhere in the United States Cordillera, we conclude that a major structural boundary accomodating dextral Cretaceous strike-slip displacement extends from southern California to western Idaho, and that terranes outboard of this boundary have been translated northward by several $100 \mathrm{~km}$; and (4) This extensive Cretaceous strike-slip boundary served as a zone of weakness within the Cordillera that localized later shortening deformation and arc magmatism. We stress that this is an ongoing research project. In this paper we summarize the evidence, part of which is of a preliminary nature, that has led us to these conclusions. Continued more detailed work by us and others will almost certainly lead to revisions in what is presented here.

GEOLOGIC FRAMEWORK

Pre-Cenozoic rocks of the United States Cordillera are shown in figure 1. Paleozoic to Jurassic rocks can be divided into two broad groups. The first group constitutes sedimentary strata deposited along or near the western continental margin. The Paleozoic component of these strata includes a passive-margin assemblage referred to as the miogeocline and offshore deep marine assemblages thrust onto the miogeocline during Paleozoic orogenic events (Burchfiel, Cowan, and Davis, 1992). Early Mesozoic strata were deposited in a short-lived back-arc basin in central Nevada and are called the basinal terrane of the Mesozoic marine province (Speed, 1978; Wyld, 2000).

The second group constitutes magmatic arc and related convergent margin assemblages. Paleozoic rocks are generally oceanic in character and are found in the 


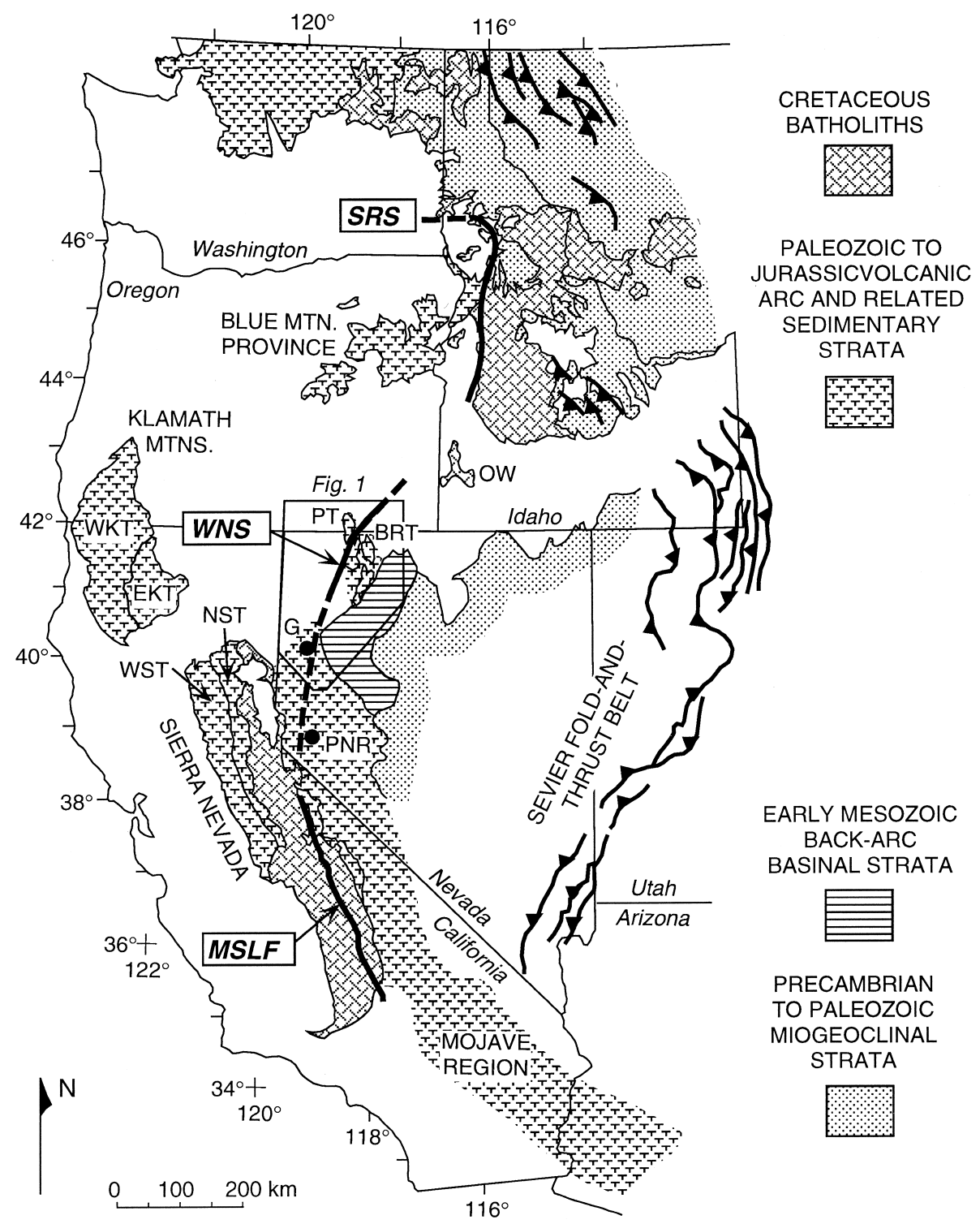

Fig. 1. Generalized pre-Cenozoic geology of the western United States Cordillera. BRT is Black Rock terrane, EKT is eastern Klamath terrane, G is Gerlach area, MSLF is Mojave-Snow Lake fault (location from Schweickert and Lahren, 1990), NST is northern Sierra terrane, PNR is Pine Nut Range, PT is Pueblo terrane, OW is Owyhee County area, SRS is Salmon River suture zone (location from Manduca, Kuntz, and Silver, 1993), WKT is western Klamath terranes, WNS is western Nevada shear zone, and WST is western Sierra terranes. Location of MSLF, SRS, and WNS shown solid where known and dashed where inferred.

western and northern Sierra Nevada, the Klamath Mountains, the Black Rock terrane (BRT), and the Blue Mountains province (fig. 1; Sharp, 1988; Miller and Harwood, 1990; Wyld, 1990; Vallier, 1995). Triassic and Jurassic rocks reflect construction of an early Mesozoic arc across the trend of older Paleozoic assemblages and possibly also the accretion of oceanic arc terranes to the margin via arc-continent collision (Saleeby and Busby-Spera, 1992). As a result, the character of early Mesozoic arc assemblages 
varies with location. To the south (south of $\sim$ latitude $38^{\circ} \mathrm{N}$ in southern California, southwest Nevada, and Arizona), where Paleozoic basement is continental crust, arc rocks are intermediate to felsic in composition and record construction of a shallow marine to subaerial continental arc (Busby-Spera, 1988). To the north of $\sim$ latitude $38^{\circ} \mathrm{N}$, arc character and basement are more variable. Paleozoic basement is either known or inferred to be accreted Paleozoic marginal basin or arc terranes in western Nevada (Pine Nut Range and vicinity; PNR in fig. 1) and the northern Sierra, eastern Klamath, and Black Rock terranes, but early Mesozoic arc assemblages in these areas vary from mafic to felsic and marine to subearial in the Pine Nut Range and northern Sierra terrane, to intermediate composition and shallow marine in the eastern Klamath terrane, to mafic and deep marine in the Black Rock terrane (Sanborn, 1960; Schweickert, 1978; Dilles and Wright, 1988; Miller and Harwood, 1990; Harwood, 1992; Wyld and Wright, 1993; Wyld, 1990 and 2000). Early Mesozoic arc assemblages in the western Sierra, western Klamaths, and Blue Mountain province are generally mafic and deep marine, with a Paleozoic basement, where exposed, of oceanic character (Harper and Wright, 1984; Sharp, 1988; Wright and Fahan, 1988; Wright and Wyld, 1994; Vallier, 1995). This seemingly complex paleogeography for early Mesozoic assemblages north of $\sim$ latitude $38^{\circ} \mathrm{N}$ is a topic we will return to later because our tectonic reconstruction of the United States Cordillera greatly simplifies this pattern.

Major shortening deformation affected the United States Cordillera in the Jurassic and Cretaceous. Jurassic shortening is most prominent within the arc terranes and the back-arc basinal terrane and occurred, depending on location, between $\sim 200$ to $150 \mathrm{Ma}$ (Early to Late Jurassic; Oldow, 1984; Dilles and Wright, 1988; Sharp, 1988; Wright and Fahan, 1988; Walker and others, 1990; Boettcher and Walker, 1993; Dunne and Walker, 1993; Girty and others, 1993; Smith and others, 1993; Wyld, Quinn, and Wright, 1996; Wyld, 1998; Rogers, ms; Wyld and Wright, 2000a). Cretaceous shortening is primarily recorded within the miogeocline to the east and resulted in development of the Sevier fold-thrust belt (fig. 1; Armstrong, 1968; Allmendinger, 1992). Most of this shortening occurred from the late Early Cretaceous (Aptian-Albian) to the early Tertiary (Lawton, 1985; Heller and others, 1986; Allmendinger, 1992; DeCelles, 1994; DeCelles, Lawton, and Mitra, 1995). Widespread arc magmatism also occurred during the mid to Late Cretaceous, resulting in emplacement of the major batholithic belts of the United States Cordillera (Sierra Nevada and Idaho batholiths and related plutons in the intervening area; fig. 1); these batholiths were emplaced primarily during the interval 120 to $70 \mathrm{Ma}$ (Smith and others, 1971; Chen and Moore, 1982; Saleeby, Sams, and Kistler, 1987; Snee and others, 1995).

Two principal regions of known or possible Cretaceous strike-slip faulting have been recognized in the United States Cordillera south of Washington state: in the southern Sierra Nevada and in western Idaho. The Mojave-Snow Lake fault (MSLF) in the Sierra Nevada (fig. 1) was originally proposed to explain the occurrence of probable Proterozoic and Lower Cambrian miogeoclinal rocks in the central Sierra Nevada which were derived from an original point of origin in the Mojave Desert (Lahren and others, 1990). As summarized by Schweickert and Lahren (1990, 1993), some $400 \mathrm{~km}$ of dextral strike-slip displacement are required to account for the current location of these rocks in the Sierra Nevada. The timing of the MSLF is constrained to be Early Cretaceous, because Late Jurassic (approx $150 \mathrm{Ma}$ ) dikes of the Independence dike swarm are offset whereas mid-Late Cretaceous plutons of the batholith $(\sim 110$ to $80 \mathrm{Ma})$ cross-cut the boundary. Younger Cretaceous strike-slip and transpressional faults of the Sierra Crest shear zone system are located near the MSLF (Busby-Spera and Saleeby, 1990; Tikoff and Teyssier, 1992; Kistler, 1993; Greene and Schweickert, 1995; Tikoff and de St. Blanquat, 1997). These faults were active in the mid-Cretaceous $(\sim 105$ to $80 \mathrm{Ma})$ and reflect dextral transpression during emplacement of the Sierra 
Nevada batholith; the total amount of displacement on this younger shear zone system is believed to be at least 20 to $70 \mathrm{~km}$.

Farther north, in eastern Oregon and western Idaho, lower Mesozoic oceanic arc and related rocks of the Blue Mountain province are juxtaposed across the Salmon River suture zone (SRS) with rocks of the North American craton (fig. 1). Abrupt contrast of initial Sr isotopic compositions across the SRS suggests that the suture is a deep-seated, near-vertical tectonic boundary that juxtaposes two distinct lithospheres: oceanic on the west and continental on the east (Armstrong, Taubeneck, and Hales, 1977; Lund, ms; Criss and Fleck, 1987). This striking feature provides a compelling argument that the SRS likely originated as a major strike-slip boundary (Lund and Snee, 1988), but thinking about this concept has been overshadowed by studies indicating that current structures along the SRS record dip-slip contractional deformation between $\sim 110$ to $75 \mathrm{Ma}$ (Strayer and others, 1989; Manduca, Kuntz, and Silver, 1993). Thus, the earlier history of the SRS is not clearly understood. Lund and Snee (1988) and Snee and others (1995) argued that older structures along the SRS indicate a period dextral transpression from 130 to $95 \mathrm{Ma}$ and concluded that this is when juxtaposition of oceanic arc assemblages with the North American continent occurred. Selverstone, Wernicke, and Aliberti (1992) and Manduca, Kuntz, and Silver (1993) concur that an early history of strike-slip faulting probably occurred along the SRS but argue that this structural history is completely obscured by younger contractional deformation and that any strike-slip displacement took place prior to $118 \mathrm{Ma}$ and possibly prior to $130 \mathrm{Ma}$. Gillaspy and others (2000), in contrast, have concluded that current structures within the SRS record dextral transpression.

The MSLF and SRS have been treated previously as separate structural boundaries in the United States Cordillera. Our new data from northwest Nevada and southeast Oregon suggest, however, that they likely connect via a Cretaceous structural boundary that we herein call the western Nevada shear zone (WNS; fig. 1). In the following sections of the paper, we provide evidence for the location and displacement history of the WNS. We then present evidence that the MSLF, WNS, and SRS are all related elements of a single structural boundary that resulted in northward translation of outboard terranes in the Early Cretaceous and subsequently controlled the location of contractional deformation and arc magmatism within this part of the Cordillera.

REGIONAL EVIDENCE FOR THE WESTERN NEVADA SHEAR ZONE (WNS)

Prior to recognition of the WNS as a distinct structural boundary, two previous studies had argued that a Cretaceous strike-slip fault system accommodating several $100 \mathrm{~km}$ of dextral displacement was likely located in this part of the Cordillera. Schweickert and Lahren $(1990,1993)$ argued, on the basis of regional stratigraphic and structural relations, that the MSLF they had identified in the southern Sierra Nevada likely continued north through northwest Nevada, although lack of detailed geologic data from northwest Nevada at that time precluded pinning down a precise location for their extended MSLF. Wyld, Quinn, and Wright (1996) subsequently provided strong support for this conclusion based on the observation that the Early Jurassic structural evolution of the Klamath Mountains and northern Sierra Nevada differs substantially from that of the Black Rock and basinal terranes in adjacent Nevada. As explained by Wyld, Quinn, and Wright (1996), these contrasting structural histories require that the Klamath Mountains and northern Sierra terranes were not located west of the Black Rock and basinal terranes in the Early Jurassic. The simplest resolution to this problem, as explained by Wyld, Quinn, and Wright (1996), is to conclude that the MSLF does, in fact, continue northward into northwest Nevada and southeast Oregon, and that all terranes to the west of this were displaced northward by $\sim 400 \mathrm{~km}$ in the Early Cretaceous from an original Early Jurassic location farther to the south. 
These conclusions are now supported by recognition of a distinct structural and terrane boundary, the WNS, in northwest Nevada and southeast Oregon, whose known and inferred location is shown in figure 2. The WNS is marked by a localized band of $\sim \mathrm{N}$-striking ductile shear zones and separates assemblages of rocks that bear no evident relation to one another, as described in more detail below.

STRATIGRAPHIC EVIDENCE FOR THE WNS

Our detailed studies in northwest Nevada and southeast Oregon, coupled with other published data from these areas, indicate that four distinct lithologic assemblages can be identified in this region, two to the west of the WNS and two to the east. Assemblages to the east include the Black Rock terrane and the basinal terrane (fig. 2). Assemblages to the west include the herein named Pueblo terrane and the informallynamed rocks of the Gerlach area (fig. 2). The Pueblo terrane and Black Rock terranes are separated by mapped shear zones of the WNS. Farther south, in the northern Black Rock range, preliminary structural data indicate that the WNS continues through the Bartlett Peak area (fig. 2). We have not yet mapped the Gerlach area in any detail, but infer, for reasons discussed below, that the WNS likely continues through this area in the vicinity of the Selenite Range, separating the Gerlach area rocks from rocks of the basinal terrane (fig. 2). In the following paragraphs we describe these four assemblages of rocks and explain how their characteristics argue for dextral strike-slip displacement along the WNS.

The Black Rock terrane contains Paleozoic to Jurassic sedimentary and volcanic strata and Triassic to Jurassic plutons (fig. 2). Paleozoic strata are predominantly sedimentary and range in age from Devonian or Mississippian to Permian (Ketner and Wardlaw, 1981; Russell, 1984; Wyld, 1990; Jones, 1990; Quinn, ms; Wyld and Wright, 1997). The most abundant Paleozoic rocks are deep marine siliciclastic strata of Mississippian age. Chert, limestone, and siliclastic strata of Mississippian to Permian age are also present. Volcanic rocks are mafic to felsic and Devonian(?) and Missippian in age; no Permian volcanic strata are present. Lower Mesozoic rocks of the Black Rock terrane include a deep marine assemblage of arc-related mafic flows and volcaniclastics, chert, limestone, and silicilastic strata, ranging in age from Triassic to Early Jurassic, that are intruded by Triassic and Early Jurassic (200-185 Ma) plutons (Russell, 1984; Wyld, 1990, 1996, 2000; Quinn, ms; Quinn, Wright, and Wyld, 1997). Middle Jurassic intrusions are rare, and no Middle or Upper Jurassic strata are known.

The adjacent basinal terrane (fig. 2) records development of a deep marine back-arc basin behind the Black Rock terrane arc and is composed mostly of shale, with much less quartz sandstone, of Late Triassic to, locally, Early Jurassic age (Speed, 1978; Lupe and Silberling, 1985; Wyld, 2000). Paleozoic basement to the basinal terrane is not exposed but is inferred to be accreted Paleozoic arc and related sedimentary rocks, such as are found in the Black Rock terrane (Speed, 1977, 1979; Wyld, 2000). The absence of Middle to Upper Jurassic strata in the Black Rock and basinal terranes likely reflects uplift and erosion during the Early to Middle Jurassic shortening deformation that affected these provinces (Oldow, 1984; Elison and Speed, 1989; Wyld, 1996; Wyld, Quinn, and Wright, 1996; Quinn, Wright, and Wyld, 1997; Rogers, ms; Wyld and Wright, 2000a).

Rocks of the Pueblo terrane and Gerlach area record a very different history and bear no evident relation to rocks of the Black Rock and basinal terranes. Rocks of the Pueblo terrane have been described by Roback and others (1987), Brown (ms), and Wolak and Wyld (2000). This terrane consists of a thick pile of andesitic to felsic volcanogenic strata, including welded ash flow tuffs and rhyolitic tuff breccias, whose facies suggest deposition in a subaerial arc setting (Wolak and Wyld, 2000). No chert, limestone, or siliciclastic strata are present in this terrane. The volcanogenic strata are intruded by several Middle Jurassic plutons (preliminary U-Pb zircon; Brown, ms). 


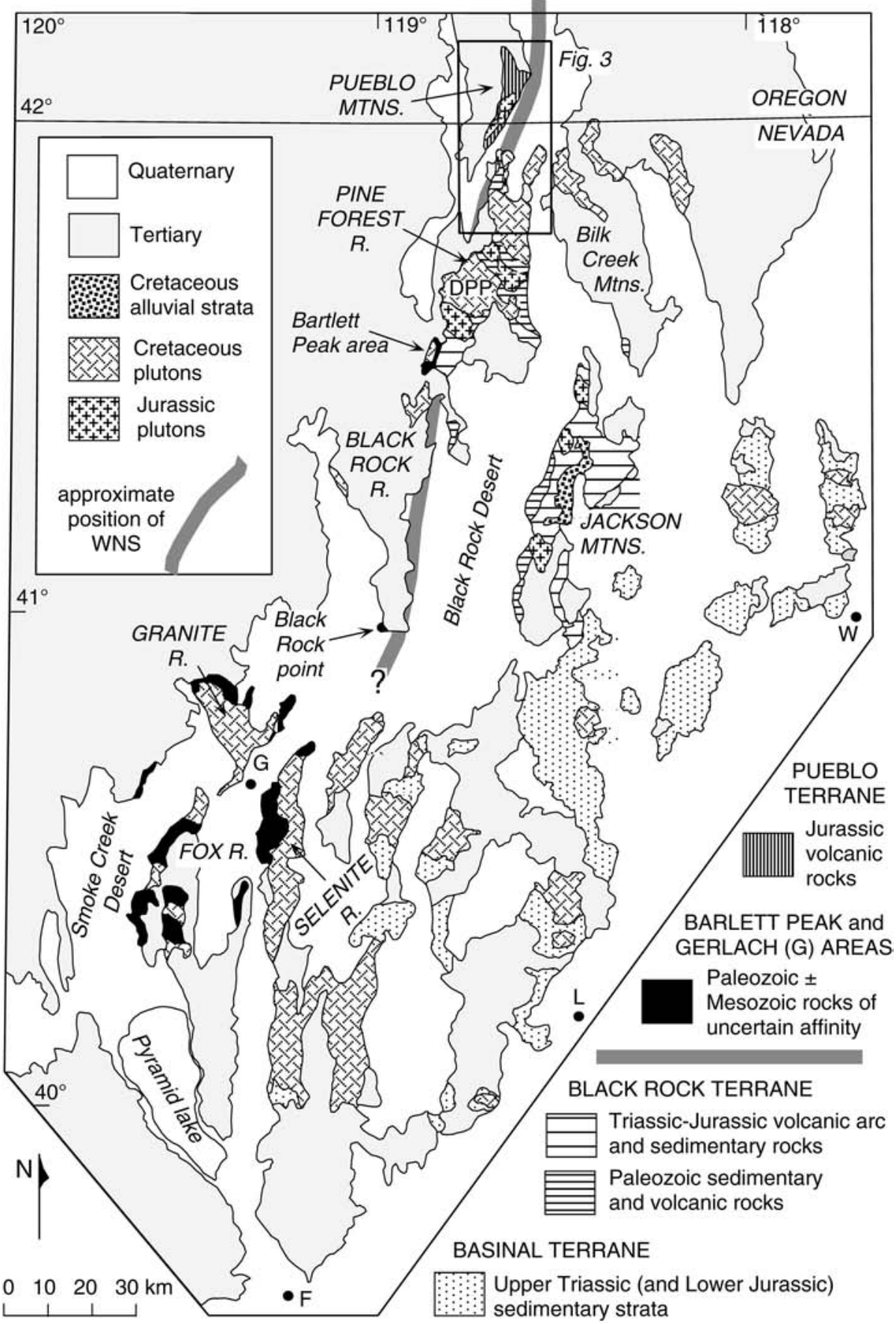

Fig. 2. Simplified geology of northwest Nevada (see fig. 1 for location). Towns are Fernley (F), Gerlach (G), Lovelock (L), and Winnemucca (W). DPP is Duffer Peak pluton. WNS drawn to show broad location without obscuring geologic units. 
Detailed field and petrologic studies argue that the plutons are comagmatic with the volcanogenic strata, which are, therefore, also interpreted to be Middle Jurassic (Wolak and Wyld, 2000). These rocks are quite different in age, composition, and depositional environment from early Mesozoic rocks of the adjacent Black Rock terrane. In addition, the Pueblo terrane records no Jurassic deformation (Wolak and Wyld, 2000), which distinguishes it from the Black Rock terrane where Jurassic deformation is widespread (Wyld, 1996; Wyld, Quinn, and Wright, 1996; Quinn, Wright, and Wyld, 1997).

Farther south, the projected WNS separates the basinal terrane from a poorly known assemblage of volcanic and sedimentary rocks in the Gerlach area (fig. 2). Although the Gerlach area rocks have previously been correlated with strata of the Black Rock and basinal terranes (Gianella and Larson, 1960; Bonham, 1969; Johnson, 1974), more recent studies indicate that this is unlikely. Two different assemblages of rocks are present in the Gerlach area. (1) A thick succession of basaltic volcanogenic rocks (mostly flows and massive breccias) is found in much of the area and is locally dated by fossils as Permian (Gianella and Larson, 1960; Bonham, 1969; Johnson, 1974; Wright and Wyld, work in progress). No similar Paleozoic rocks are known in the Black Rock terrane. (2) A sedimentary succession consisting of well-bedded carbonaceous argillite and thick quartz sandstone and carbonate horizons is found in the Fox Range and appears to have been deposited in a shallow marine environment (Bonham, 1969; Thiesse, ms; Wright and Wyld, work in progress). The age of these rocks is uncertain, fossil evidence for both Early Jurassic (Bonham, 1969) and Mississippian (Thiesse, ms; Thiesse and Wardlaw, 1985) ages having been cited. Regardless of uncertainties about the age of Fox Range rocks, it is evident that these rocks have no counterpart in the adjacent basinal or Black Rock terranes.

The relations described above provide strong evidence that a major terrane boundary occurs within this part of the Cordillera, separating the Black Rock and basinal terranes from the Pueblo terrane and rocks of the Gerlach area and along which are juxtaposed supracrustal Paleozoic to early Mesozoic rock assemblages with very different stratigraphies, depositional environments, and magmatic and deformational histories. As noted above, the Pueblo and Black Rock terranes are separated by mapped shear zones of the WNS whose trace strikes south toward the boundary between the basinal terrane and the Gerlach area rocks (fig. 2). We conclude, therefore, that the WNS separates these unrelated lithologic assemblages and that this structural boundary records significant terrane displacement.

In order to evaluate the nature and amount of terrane displacement along the WNS, several points must be considered. First, the Black Rock and basinal terranes can be tied to the adjacent continental margin during their evolution (Speed, 1978; Lupe and Silberling, 1985; Darby, Wyld, and Gehrels, 2000; Wyld, 2000). Second, there is no evidence that the WNS marks a suture zone reflecting collision of allochthonous terranes with this part of the margin; there are no blueschists, ophiolites, or melanges along the boundary, nor is there any evident shared structural history across the boundary that is consistent with collisional tectonism. We conclude, therefore, that terrane juxtaposition across the boundary more likely reflects strike-slip displacement of the Pueblo terrane and Gerlach rocks from somewhere either to the north or the south.

Displacement of the Pueblo terrane and Gerlach rocks from an original position to the north is considered unlikely for three reasons. First, regional structural relations in the United States Cordillera indicate that the Klamath Mountains province and northern Sierra terrane could not have resided west of the Black Rock terrane and basinal terrane in the Early Jurassic, and that the two western assemblages most likely originated several hundred kilometers to the south (Wyld, Quinn, and Wright, 1996). 
In particular, the Black Rock terrane and adjacent basinal terrane record major shortening deformation in the Early Jurassic, whereas terranes in the Klamath Mountains and northern Sierra experienced either extension or uninterrupted deposition during this time frame. As discussed by Wyld, Quinn, and Wright (1996), this spatial arrangement of deformation cannot be reconciled with any current understanding of stresses associated with plate convergence. If, however, terranes to the west are restored to a position several hundred kilometers south of their current location, the spatial arrangement of deformation becomes much more reasonable: the Klamath Mountains and northern Sierra terrane are restored to a position south of the Gerlach area where they are adjacent to other areas of the western Cordillera that experienced extensional to neutral tectonism in the Early Jurassic; and the Blue Mountain province, which in part experienced shortening deformation in the Early Jurassic, restores to a position adjacent to the Black Rock terrane, which has a similar Early Jurassic contractional history. Because the Pueblo terrane and Gerlach area rocks are located between the Black Rock terrane/basinal terrane and the Klamath Mountains/ northern Sierra terrane, this set of relations strongly suggests that a southern point of origin is also likely for the intervening Pueblo terrane and Gerlach area rocks.

Second, Jurassic arc assemblages to the north of the Pueblo terrane, in eastern Oregon, northern Washington, and the Canadian Cordillera, are largely oceanic in character (strata deposited in a marine environment and largely mafic in composition; Monger and others, 1991; Gabrielse and Yorath, 1991; Saleeby and Busby-Spera, 1992; Vallier, 1995) and do not provide a good match for continental arc rocks of the Pueblo terrane. Third, although some felsic subaerial volcanogenic strata are locally present in Jurassic arc terranes of the Canadian Cordillera (Monger and others, 1991), the terranes containing these strata are all allochthonous and are widely considered to have been displaced at least some distance to the north from an original position farther south (Gabrielse and Yorath, 1991, and references therein). This makes it unlikely that the Pueblo terrane is a southward-displaced fragment from any of these Canadian terranes.

Because of the problems cited above with a northern source, we consider it much more likely that the Pueblo terrane and Gerlach area rocks originated to the south, and we focus, therefore, on evidence for a southern point of origin for rocks west of the WNS. The strongest evidence comes from the continental character (intermediate to felsic composition and probable deposition in a subaerial environment) of Jurassic arc rocks in the Pueblo terrane and the lack of any interlayered sedimentary rocks. Similar Jurassic continental arc assemblages in the United States Cordillera are found primarily only south of latitude $39^{\circ} \mathrm{N}$ (Schweickert, 1978; Busby-Spera, 1988; Dilles and Wright, 1988; Wright and Fahan, 1988; Harwood, 1992; Saleeby and Busby, 1992; Vallier, 1995). In particular, Jurassic arc assemblages south of the Pine Nut Range (PNR in fig. 1), are entirely continental and consist of intermediate to felsic volcanogenic strata deposited in a subaerial environment and interlayered in most places only sparsely with sedimentary strata. Farther north, in the northern Sierra terrane and Klamath Mountains, Jurassic arc strata are largely deep marine and intermediate to mafic in composition. The only exception is in the northernmost northern Sierra terrane, where some Jurassic volcanogenic rocks are felsic; however, these strata were deposited in a shallow marine environment and are interlayered with sedimentary rocks (Harwood, 1992). From these relations, we conclude that the Pueblo terrane was most likely derived from a position near or south of the Pine Nut Range. This implies dextral displacement of over $300 \mathrm{~km}$.

Determining the potential point of origin of the Gerlach area rocks is more difficult because mafic Permian volcanic assemblages are known from the Blue Mountain province, Klamath Mountains, Sierra Nevada, and southwest Nevada (Speed, 
1977; Miller and Harwood, 1990; Vallier, 1995), and because of uncertainties about the age of the sedimentary successsion in the Gerlach area. It is notable, however, that the sedimentary succession in the Gerlach area appears strikingly similar in lithology, composition, and depositional environment to Upper Triassic and Lower Jurassic strata of the Pine Nut Range and vicinity (Dilles and Wright, 1988; Wyld and Wright, 1993, and work in progress in the Gerlach area). Like the Gerlach area sedimentary succession, the Pine Nut area strata include shallow marine carbonates (of the Upper Triassic Oreana Peak Formation), well-bedded carbonaceous argillites (of the Lower Jurassic Gardnerville Formation), and shallow marine quartz sandstone (of the Lower or lower Middle Jurassic Preachers Formation). In contrast, as noted previously, the Gerlach area sedimentary succession bears little similarity to the deep marine, mudstonedominated sedimentary strata of the basinal terrane directly to the east (fig. 2). These relations, while inconclusive at the present time, suggest the possibility that Gerlach area sedimentary strata originated near the Pine Nut Range in the early Mesozoic. This is consistent with the sense and amount of displacement argued above for the Pueblo terrane.

Based on the relations outlined above, we conclude that the sense of strike-slip displacement along the WNS is dextral and that the amount of displacement is on the order of $300 \mathrm{~km}$. The timing of this displacement is constrained by the following: it must postdate the youngest rocks displaced, which are Middle Jurassic (Pueblo terrane); and it must predate contractional deformation that occurred along the WNS in the interval 115 to $108 \mathrm{Ma}$ (discussed further below). Strike-slip displacement occurred, therefore, sometime in the interval Late Jurassic-Early Cretaceous. In a later section, we will provide more evidence, based on regional relations, that dextral strike-slip displacement along the WNS most likely occurred in the Early Cretaceous.

STRUCTURAL RELATIONS ALONG THE WNS

The terrane boundary documented in the previous section is marked in areas that we have mapped in detail, by mid-Cretaceous ductile shear zones. In this section, we describe structural features associated with these shear zones and constraints on the timing of shear zone deformation. Our principal areas of focus will be the Pueblo Mountains and the northern Pine Forest Range (fig. 2), where detailed relations have been established. Additional preliminary data from the Bartlett Peak area in the northeast Black Rock Range (fig. 2) will also be described.

Pueblo Mountains and Northern Pine Forest Range.-A summary map of the Pueblo Mountains and northern Pine Forest Range is shown in figure 3. The Pueblo terrane is present in the Pueblo Mountains, where it consists of volcanogenic strata and several plutons, and in the extreme northwestern Pine Forest Range, where it consists mostly of the herein named Baltazor pluton plus minor volcanogenic strata (fig. 3). The Baltazor pluton is a distinctive intrusion consisting of a fine-grained mafic phase and an intermingled coarser-grained intermediate phase that can be recognized in both the Pine Forest Range and across a Quaternary valley, in the southeastern Pueblo Mountains (fig. 3; Wright and Wyld, work in progress; Wolak and Wyld, 2000). This pluton yields a U-Pb zircon age of $181.7 \pm 1.2 \mathrm{Ma}$ (J.E. Wright, unpublished data ${ }^{1}$ ). Paleozoic to Jurassic rocks of the Black Rock terrane are present farther south and east in the Pine Forest Range (fig. 3). These rocks include deformed metapelite and metabasalt of inferred Devonian to Carboniferous age, intruded by Triassic orthogneiss (Wyld and Wright, 1997) and Jurassic plutons ( 190 Ma; U-Pb zircon; Wright, unpublished data). The Cretaceous Granite Mountain plutonic complex intrudes the

${ }^{1}$ All unpublished U-Pb zircon ages by J. E. Wright cited in the paper will be published and described in a subsequent more detailed paper. 


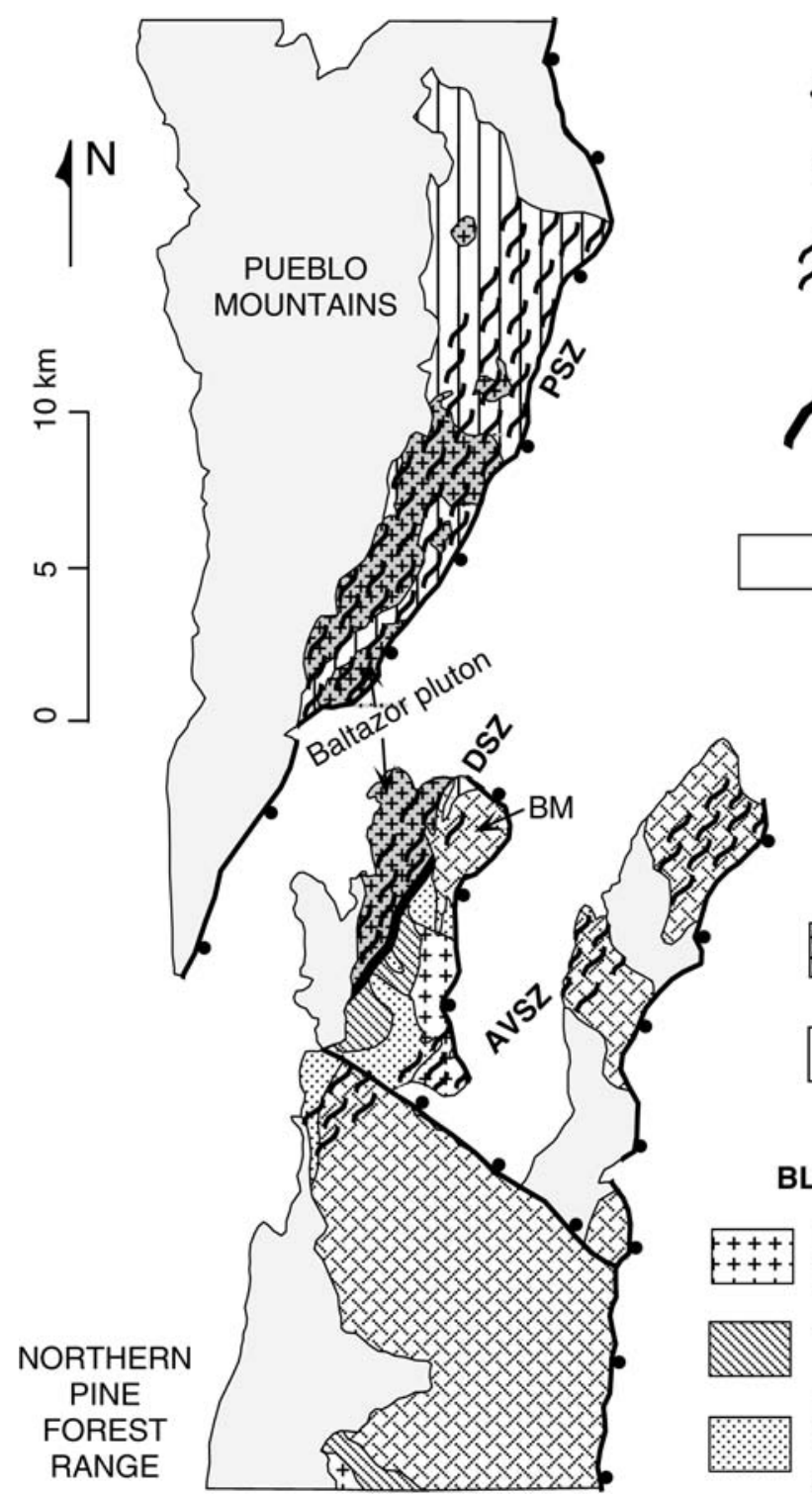

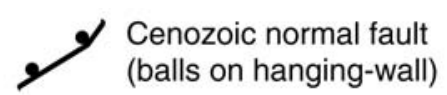

Cretaceous ductile shear zones AVSZ (Antelope Valley

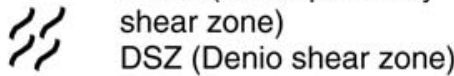
PSZ (Pueblo shear zone)

high strain zone (ductile fault boundary)

\section{Quaternary} strata

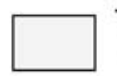
Tertiary strata

Fig. 3. Simplified geology of the Pueblo Mountains and northern Pine Forest Range (for location, see fig. 2). Map data from Roback and others (1987), Wright and Wyld (unpublished data), and Wolak and Wyld (2000 and work in progress). Geochronologic data (U-Pb zircon) from Brown (ms), Wyld (1996), Quinn, Wright, and Wyld (1997), Wyld and Wright (1997), and Wright (unpublished data).

Black Rock terrane and the southeasternmost portion of the Pueblo terrane (figs. 2 and 3). This complex consists of five phases (not distinguished in fig. 3), including quartz diorite, quartz monzodiorite, quartz monzonite, granodiorite, and granite that range in age from 115 to $108 \mathrm{Ma}$ (U-Pb zircon; Wright and Wyld, unpublished data).

Three ductile shear zones are recognized in this area, all characterized by mylonitic rocks. The Pueblo shear zone occurs on the east side of the Pueblo Mountains and is up to $3 \mathrm{~km}$ wide (fig. 3). One ${ }^{40} \mathrm{Ar} /{ }^{39} \mathrm{Ar}$ biotite analysis from the 
greenschist facies rocks of this shear zone yields a poorly-defined plateau at $\sim 95 \mathrm{Ma}$ (Brown, ms), which is interpreted to reflect an approximate age for deformation within the Pueblo shear zone. The Denio shear zone occurs along the southeast side of the Baltazor pluton in the Pine Forest Range, at the boundary between the Pueblo and Black Rock terranes (fig. 3). This shear zone records intense ductile strain under amphibolite grade conditions. Its age is constrained by the $115.0 \pm 1.1 \mathrm{Ma}$ age of a phase of the Granite Mountain plutonic complex that occurs in the vicinity of Black Mountain (BM in fig. 3). This 115 Ma plutonic phase of the complex crosscuts the Denio shear zone (fig. 3) but is also weakly deformed along it. The Denio shear zone is interpreted, therefore, to have been active prior to and during $115 \mathrm{Ma}$. The Antelope Valley shear zone occurs primarily within the Granite Mountain plutonic complex, but also crosscuts parts of the Black Rock terrane (fig. 3). This shear zone deforms an older phase of the Granite Mountain complex, which has been dated at $108.2 \pm 0.6 \mathrm{Ma}$, but is also cut by a younger undeformed phase of the plutonic complex, whose U-Pb zircon age is analytically indistinguishable at $108.6 \pm 1.1 \mathrm{Ma}$ from that of the older deformed phase. We thus conclude that the Antelope Valley shear zone was active at $108 \mathrm{Ma}$.

Structural data from the three shear zones are shown in figure 4. All the shear zones strike $\sim \mathrm{N} 25 \mathrm{E}$ and display a well-developed mylonitic foliation and down-dip stretching or mineral lineation. Foliation in the shear zones dips steeply in all cases, although the dip direction varies from southeast to northwest (fig. 4). To determine the original dip of the shear zones, Tertiary tilting must be removed. When this is done, the Pueblo shear zone dips $\sim 80^{\circ}$ to the southeast and the Denio shear zone dips $\sim 85^{\circ}$ to the southeast, while the Antelope Valley shear zone appears unlikely to have had an original dip shallower than $\sim 55^{\circ}$ to $60^{\circ}$ to the northwest.

The lineation in all three shear zones is well-developed and defined by both stretched clasts (in volcaniclastic rocks) and preferred alignment of syntectonic metamorphic minerals. This lineation is everywhere oriented in a general down-dip direction relative to the mylonitic foliation (fig. 4). Fabrics within the shear zones, therefore, reflect subhorizontal shortening and subvertical stretching. Shear sense indicators are common within the Pueblo and Antelope Valley shear zones and include well-developed S-C fabrics and sigma structures associated with feldspar porphyroclasts. These shear sense indicators consistently indicate top-to-the-northwest shear for the Pueblo shear zone and top-to-the-southeast shear for the Antelope Valley shear zone. We have found few unambiguous shear sense indicators within the high strain Denio shear zone; however, those we have found indicate top-to-the-northwest shear sense.

A schematic cross section across the Pueblo Mountains-northern Pine Forest Range is shown in figure 5. This cross section is designed to show relations as they existed during Cretaceous shear zone development, prior to Cenozoic extension and basin-and-range formation in the region. It emphasizes the steep dip of the shear zones and their relative sense of displacement, in addition to cross-cutting relations of the Granite Mountain plutonic complex relevant to age constraints on shear zone development.

Bartlett Peak area.-Preliminary mapping indicates that similar structural relations are found to the south and along strike from the Pueblo Mountains-northern Pine Forest Range shear zones in the Bartlett Peak area (fig. 2). Here, a north-northweststriking and steeply north-northeast-dipping ductile shear zone juxtaposes mafic volcanic strata of the Black Rock terrane (to the east) against mafic to felsic igneous rocks of uncertain affinity (to the west) and is intruded by plutonic rocks that are compositionally and texturally indistinguishable from the Cretaceous Granite Mountain plutonic complex. A schematic cross section based on our preliminary data from this area is shown in figure 6. Key features observed in this area are as follows: (1) Black 


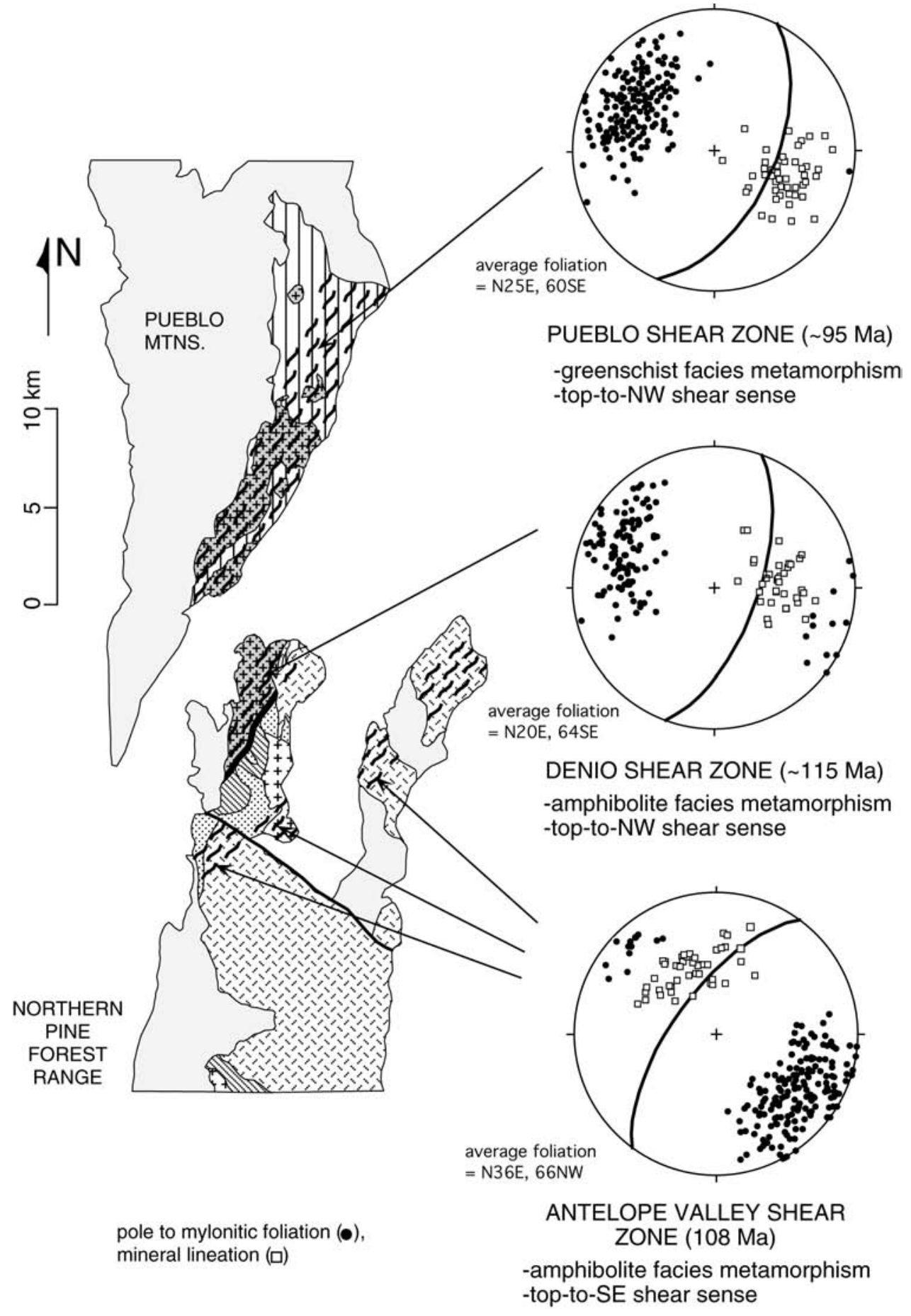

Fig. 4. Structural data, metamorphic grade, and ages of mid-Cretaceous Pueblo Mountains and northern Pine Forest Range shear zones. Structural data for Pueblo shear zone from Wolak and Wyld (2000 and work in progress). Structural data for Denio and Antelope Valley shear zones from Wright and Wyld (work in progress). Age data for Pueblo shear zone from Brown (ms). Age data for Denio and Antelope Valley shear zones from Wright (unpublished data). Map patterns and symbols same as in figure 3. 


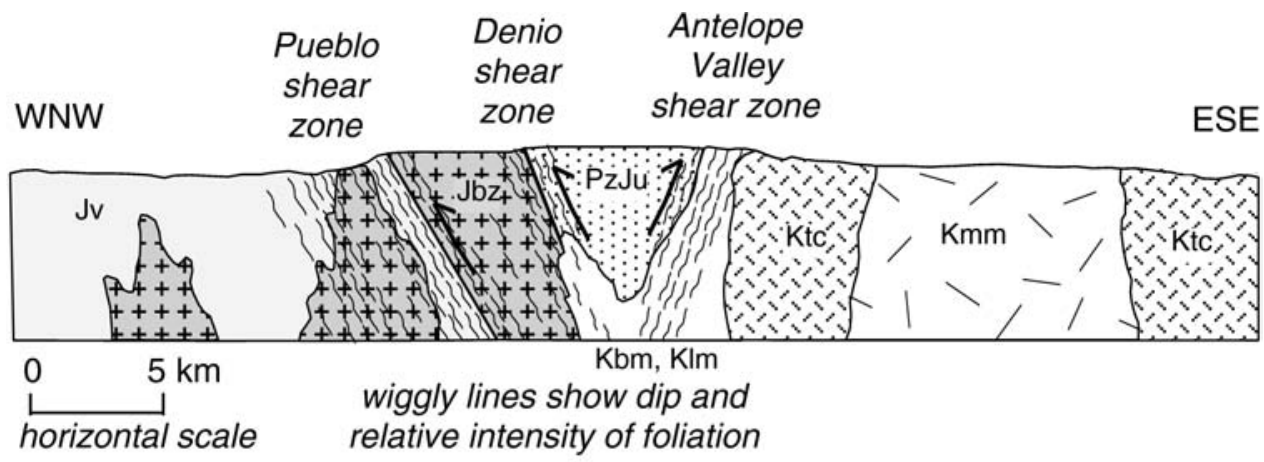

Pueblo terrane

Middle Jurassic plutons: $\mathrm{Jbz}$ is Baltazor pluton (182 Ma)

Jv

Middle Jurassic intermediate to felsic volcanogenic rocks
Granite Mtn. plutonic complex

Kmm Mahogany Mtn. granite

Thacker Cnyn. granodiorite
(108 Ma)

Kbm, Black Mtn. and Lone Mtn.

$\mathrm{KIm}$ quartz monzodiorites

(Kbm: $115 \mathrm{Ma}, \mathrm{KIm}: 108 \mathrm{Ma})$

\section{Black Rock terrane}

Fig. 5. Schematic cross-section cartoon depicting structural relations across the Pueblo Mountains and northern Pine Forest Range in mid-Cretaceous time, prior to Basin-and Range extension. Based on data from Wolak and Wyld (2000 and work in progress) and Wright and Wyld (work in progress). Geochronologic data is U-Pb zircon from Wyld and Wright (1997) and Wright (unpublished data).

Rock terrane strata are undeformed far from the shear zone but grade progressively into mylonitic rocks toward the shear zone. (2) The mafic to felsic igneous rocks of uncertain affinity are strongly deformed mylonites within the shear zone. (3) A quartz diorite to monzodiorite pluton texturally and compositionally similar to the 115 to 108 Ma phases of the Granite Mountain plutonic complex farther north cuts the shear zone but is weakly deformed by shear zone fabrics, whereas an undeformed granodioritic pluton that is indistinguishable from the undeformed 108 Ma phase of the Granite Mountain complex cuts across deformed rocks. (4) Foliation within the shear zone and in the crosscutting deformed pluton strikes $\sim \mathrm{N} 10 \mathrm{~W}$ and dips $\sim 80 \mathrm{NE}$. A welldeveloped mineral lineation trends $\sim \mathrm{S} 55 \mathrm{E}$ and plunges $\sim 70^{\circ}$, downdip of the foliation. Shear sense indicators include sigma structures associated with feldspar porphyroclasts and indicate top-to-the-southwest shear. These features are very similar to those found along the shear zones in the northern Pine Forest Range and Pueblo Mountains.

Summary.-The relations described above indicate that a localized, north-trending mid-Cretaceous shear zone system occurs along and near the boundary of the Pueblo and Black Rock terranes in the Pueblo Mountains and northern Pine Forest Range and that a shear zone of similar character, orientation, and age occurs along strike of this to the southwest in the Black Rock Range. Although we have not mapped the intervening area in detail, published maps (Willden, 1964; Smith, ms and 1973) indicate that this 


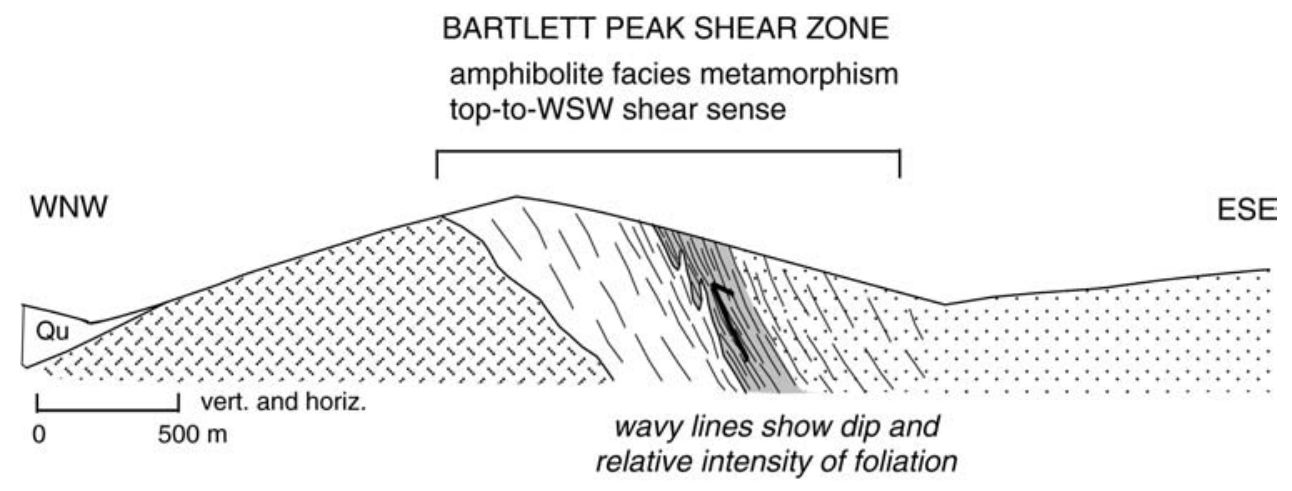

$\underline{\text { mid-Cretaceous plutons }}$

(inferred ages by correlation with compositionally similar dated plutons

in northern Pine Forest Range)

E: undeformed (108 Ma?)

deformed (115-108 Ma?)

$\therefore$ Black Rock terrane: Upper Triassic- Jurassic(?) basaltic volcanogenic rocks

mylonitic mafic to felsic volcanic and plutonic rocks of uncertain age or affinity

Fig. 6. Schematic cross section depicting relations in the Bartlett Peak area of the northern Black Rock Range (see fig. 2 for location). Qu is Quaternary. Based on unpublished data of Wright and Wyld.

area is underlain primarily by Cenozoic deposits and the Duffer Peak pluton (DPP in fig. 2), which is undeformed (see also Wyld, ms) and, therefore, likely postdates the shear zone. The shear zone system projects along strike to the southwest from the Bartlett Peak area directly toward the boundary between the basinal terrane and rocks of the Gerlach area (fig. 2). Our preliminary mapping in this area has so far not revealed the presence of any ductile shear zones near this boundary; however, the boundary itself is nowhere exposed as it is either covered by Cenozoic strata or intruded by large undeformed plutons (fig. 2). Our working hypothesis is that the entire terrane boundary from the Gerlach area to the Pueblo Mountains is characterized by ductile shear zones such as we have found in the north, although the shear zone system may be obscured in many places by younger rocks. We, therefore, use structural and age relations within the shear zones we have mapped in the north as the basis for analyzing the structural evolution of the entire tectonic boundary. In the following section, we analyze these structural and age relations in more detail in the context of the displacement and deformation history of the WNS.

\section{DISPLACEMENT AND DEFORMATION HISTORY OF THE WNS}

In the previous sections, we have provided evidence that a tectonic boundary extends from the Gerlach area of western Nevada to the Pueblo Mountains in southeast Oregon along which outboard terranes have been displaced north by dextral strike-slip faulting, and that this boundary is currently marked by a narrow band of $\sim \mathrm{N}$-striking, steeply-dipping ductile shear zones. The first question to be addressed is whether the ductile shear zones reflect the strike-slip displacement history of the boundary. This can be done by considering structural relations within the shear zones.

Lineation orientation and shear sense indicators within ductile shear zones are commonly used to determine the sense of displacement along these zones. Utilizing the standard approach for this type of analysis, the ductile shear zones marking the 
WNS record dip-slip, reverse-sense contractional deformation. This conclusion is based in part on the consistently steep plunge of the stretching and mineral lineations within the shear zones (fig. 4). The shear zones are steeply-dipping, however, and are located along a boundary for which there is independent evidence of strike-slip displacement. It is possible, therefore, that the shear zones reflect transpressional tectonism (Sanderson and Marchini, 1984; Dewey, Holdsworth, and Strachan, 1998). According to modelling studies (Fossen and Tikoff, 1993; Fossen, Tikoff, and Teyssier, 1994; Dutton, 1997), the orientation of lineations within transpressional shear zones may not accurately reflect the displacement history of the shear zones, because shortening perpendicular to the shear zone boundaries results in subvertical stretching, which may lead to steeply plunging lineations even when the overall displacement history of the shear zone is dominantly strike-slip. This possibility needs to be considered for the shear zones marking the WNS.

Any ductile shear zone may develop a foliation that reflects the shortening plane and a stretching lineation that reflects the extension direction of the finite strain ellipsoid. To determine shear sense, however, asymmetric structures such as mantled porphyroclasts or S-C fabrics must be evaluated on planes normal to the vorticity vector (Passchier, 1997, 1998; Tikoff and Green, 1997). In practice, this means that shear sense must be evaluated by viewing planes in which asymmetric shear sense indicators are best developed. In transpressional shear zones with a subvertical foliation and stretching lineation, these planes will be broadly horizontal; in this case, the subhorizontal plane (perpendicular to the lineation) will show well-developed shear sense indicators that reflect a consistent sense of shear, whereas the subvertical plane (perpendicular to the foliation and parallel to the lineation) will show a lack of strong or consistent shear sense indicators (Passchier, 1997, 1998; Tikoff and Green, 1997). This contrasts with structures developed in dip-slip simple shear zones, where the plane perpendicular to the foliation and parallel to the lineation will show welldeveloped and consistent shear sense indicators, and the plane normal to the lineation will show no clear evidence of non-coaxial strain.

According to these criteria, we must conclude that the shear zones along the WNS reflect reverse-sense simple shear, not transpression. This conclusion is based on the fact that the Pueblo, Antelope Valley, and Bartlett Peak shear zones all display well-developed and consistent reverse sense-of-shear indicators (sigma-structure mantled porphyroclasts and/or S-C fabrics) in the vertical plane perpendicular to the foliation and parallel to the lineation, with no evidence of non-coaxial strain in the plane normal to the lineation. Rocks in the high strain Denio shear zone do not display well-developed shear sense indicators on any surface, probably in part because there are few porphyroclasts in these rocks; however, the few we have observed are reversesense indicators in the vertical plane perpendicular to the foliation and parallel to the lineation. At least three and possibly all of the four shear zones, therefore, record contractional, dip-slip deformation, with no obvious strike-slip component.

Despite the fact that there is little structural evidence for a strike-slip component of displacement in the shear zones that mark the WNS, there are three compelling lines of evidence that these contractional shear zones represent reactivation of an older strike-slip tectonic boundary.

1. The shear zones separate distinct lithostratigraphic terranes that have no evident relation to one another. Dip-slip displacement along steeply-dipping shear zones is unlikely to result in this arrangement, unless the amount of displacement is quite large. If this were the case, however, one would expect to see significantly different crustal levels exposed across the shear zones, and this is not the case. We conclude, therefore, that unrelated terranes in this area were originally juxtaposed along a strike-slip boundary prior to shear zone 
development and that this strike-slip boundary was later reactivated during younger shortening deformation in the region. Current structures within the shear zones are thereby interpreted as late-stage structures that overprint and obliterate evidence of earlier strike-slip deformation.

2. The steep dip of the shear zones is inconsistent with the expected orientation of contractional shear zones developed within the ductile part of the crust. Specifically, contractional shear zones formed in the ductile part of the crust are typically gently dipping (McClay, 1992). This suggests that the steeplydipping contractional shear zones marking the WNS reflect reactivation of an older, steeply-dipping structural boundary that contolled the orientation of structures formed during younger contractional deformation. The obvious candidates for an older, steeply dipping boundary are normal or strike-slip faults. In view of the regional evidence for strike-slip faulting in this area, we consider the most likely explanation for the orientation anomaly of the shear zones to be that younger contractional deformation in the area reactivated an older, subvertical strike-slip boundary.

3. The shear zones clearly reflect Cretaceous shortening strain along a localized trend. This is in stark contrast to relations farther to the east and west, where there is little to no Cretaceous shortening deformation (Wyld, 1996, 1998; Brown, ms; Quinn, Wright, and Wyld, 1997; Rogers, ms; Wolak and Wyld, 2000; Wyld and Wright, 2000a). There is no obvious rheological reason why Cretaceous shortening in this part of the Cordillera should be restricted to a localized zone. We conclude, therefore, that the mid-Cretaceous shear zones reflect reactivation of an older zone of weakness within the crust of this area. While this line of evidence does not directly indicate the nature of the older boundary, it does support the conclusions in points 1 and 2 above that the shear zones marking the WNS reflect reactivation of an older structure.

In summary, we conclude that the WNS records a two-stage history, the first stage being dextral strike-slip faulting that juxtaposed unrelated terranes and produced a subvertical zone of weakness within the crust, and the second stage being shortening deformation that reactivated the older strike-slip boundary as steeply-dipping, reversesense contractional shear zones. Thus, we conclude that the current structures within shear zones of the WNS record only the latest stage in the structural history of this boundary.

The second question to be considered in this area concerns the timing of strike-slip displacement along the WNS. As noted earlier, the youngest known rocks displaced by strike-slip faulting along the boundary are Middle Jurassic, and this provides an older age limit for strike-slip displacement. Contractional deformation within the shear zones marking the WNS is interpreted to postdate strike-slip displacement, and the age of these shear zones, therefore, provides an upper age limit. The age of deformation within the various shear zones is not uniform, however. The oldest dated shear zone is the Denio shear zone which was active prior to and during $115 \mathrm{Ma}$. The Antelope Valley shear zone was active at $108 \mathrm{Ma}$, and, by correlation with dated plutons, the Bartlett Peak shear zone is inferred to be the same age. The age of the Pueblo shear zone is less well constrained; conservatively, the one biotite ${ }^{40} \mathrm{Ar} /{ }^{39} \mathrm{Ar}$ plateau age of $\sim 95 \mathrm{Ma}$ from this shear zone should be interpreted as a minimum age for shear zone development as it may reflect cooling below the Ar closure temperature of biotite postdating deformation. Additional complications that should be considered are structural relations along the various shear zones, which indicate that the Pueblo, Antelope Valley, and Bartlett Peak shear zones clearly record only contractional deformation, whereas it is possible that the Denio shear zone may record transpressional deformation. We thus conclude that a younger age limit for strike-slip displace- 
ment along the WNS, defined by the age of younger contractional structures, is 108 Ma. Available direct age constraints thus indicate that strike-slip displacement along the WNS took place sometime in the interval Late Jurassic to Early Cretaceous, prior to $108 \mathrm{Ma}$.

Further refinement of these timing constraints can be made by considering regional relations. First, a variety of geologic relations in the United States Cordillera indicate that deformation during the Late Jurassic time frame included some component of sinistral strike-slip displacement (Ave Lallemant and Oldow, 1988; Harper, Saleeby, and Norman, 1985; Newton, 1986; Glazner, Bartley, and Carl, 1999). This is consistent with plate motion reconstructions suggesting that the Farallon plate was subducting obliquely, in a sinistral sense, beneath North America during the Late Jurassic (Engebretson, Cox, and Gordon, 1985), although there are inherent uncertainties is these reconstructions prior to the mid-Cretaceous. Second, the time frame from $\sim 140$ to $120 \mathrm{Ma}$ in the United States Cordillera was characterized by a notable scarcity of subduction-related magmatism or regional shortening deformation; this is in contrast with the preceding Jurassic time frame and the subsequent Cretaceous time frame (after $120 \mathrm{Ma}$ ) when voluminous subduction-related magmatism and significant regional shortening deformation occurred (see summaries in Burchfiel, Cowan, and Davis, 1992; Smith and others, 1993, and references therein; and Wyld and Wright, 2000b). Voluminous magmatism and significant upper plate shortening deformation are both hallmarks of rapid orthogonal relative convergence between the plates at a convergent margin (Dewey, 1980; Cross and Pilger, 1982; Verplanck and Duncan, 1987; Gill, 1981, p. 27-28), and the Jurassic and post-120 Ma Cretaceous evolution of the United States Cordillera, therefore, imply a significant orthogonal component of convergence during these time frames. In contrast, the general lack of arc magmatism or shortening deformation in the United States Cordillera during the Early Cretaceous from $\sim 140$ to $120 \mathrm{Ma}$ is suggestive of a period of reduced orthogonal convergence and would likewise be consistent with a period of highly oblique convergence associated with upper plate strike-slip faulting (Smith and others, 1993; Wyld and Wright, 2000b). Based on all these relations, we consider it highly unlikely that dextral displacement along the WNS occurred in the Late Jurassic and conclude that strike-slip displacement along the WNS occurred in the Early Cretaceous prior to $108 \mathrm{Ma}$ and potentially during the $\sim 140$ to 120 Ma magmatic and orogenic lull.

According to the plate motion reconstructions of Engebretson, Cox, and Gordon (1985), the Farallon plate was subducting obliquely in a sinistral-sense beneath North America from $\sim 140$ to $115 \mathrm{Ma}$ and orthogonally from $\sim 115$ to $100 \mathrm{Ma}$, which appears to contradict our evidence for dextral strike-slip displacement between 140 to $108 \mathrm{Ma}$. It is beyond the scope of this paper to address this apparent conflict in detail; however, we do note several relevant points. First, the plate motions reconstructions of Engebretson, Cox, and Gordon (1985) are based on seafloor magnetic anomalies tied to a hot-spot reference frame and are not as well-constrained for time periods prior to $\sim 84$ Ma because detailed reconstructions during the Cretaceous long normal superchron (120-84 Ma) are difficult, and reconstructions prior to this time are complicated by the scarcity of older seafloor from which to obtain data (B. Housen, personal communication, 1999). Determination of plate tectonic interactions prior to 84 Ma may thus best be addressed through a combination of paleomagnetic and geologic information. Second, the plate motion reconstructions of Engebretson, Cox, and Gordon (1985) for the time period from 140-100 Ma do not completely coincide with geologic data from the United States Cordillera, even independent of the evidence we present in this paper. In particular, Engebretson, Cox, and Gordon (1985) show that: (A) there was rapid orthogonal convergence between the Farallon plate and North America between $\sim 135$ to $120 \mathrm{Ma}$, which is inconsistent with the scarcity of arc magmatism in the United 
States Cordillera during this time frame (Wyld and Wright, 2000b); and (B) the Farallon plate was subducting obliquely in a sinistral sense beneath North America during the Early Cretaceous prior to $\sim 120 \mathrm{Ma}$, although there is no direct evidence in the United States Cordillera for sinistral strike-slip displacement during this time frame. These discrepancies open the possibility that some elements of the FarallonNorth America plate motion reconstructions for the Early Cretaceous are not yet fully understood.

REGIONAL CORRELATIONS AND IMPLICATIONS

The data we have described above support the following history for the WNS: dextral strike-slip faulting in the Early Cretaceous, sometime between 140 to $108 \mathrm{Ma}$, resulting in displacement of outboard terranes $\sim 300$ to $400 \mathrm{~km}$ to the north; followed by shortening deformation, localized along the older strike-slip boundary and manifested by dip-slip ductile shear zones, in the mid-Cretaceous during emplacement of 115 to 108 Ma plutons. Below we discuss data indicating that the WNS is part of a much larger structural boundary within the United States Cordillera that accommodated displacement of outboard terranes several $100 \mathrm{~km}$ to the north during the Early Cretaceous and indicating that this boundary exerted an important control on the location of subsequent Cretaceous shortening deformation and magmatism within the arc region.

Correlations to the south and north.-The Cretaceous history of the WNS is very similar to that of the southern Sierra Nevada. In particular, the Mojave-Snow Lake fault (MSLF) accommodated $\sim 400 \mathrm{~km}$ of dextral strike-slip displacement in the Early Cretaceous, sometime between 150 to $110 \mathrm{Ma}$, along the crest of the range in the southern Sierra (Lahren and others, 1990; Schweickert and Lahren, 1990); and this was followed, in the same general area, by development of ductile shear zones of the Sierra Crest shear zone system, which records dextral transpression during emplacement of the Sierra Nevada batholith from $\sim 105$ to 80 Ma (Busby-Spera and Saleeby, 1990; Tikoff and Teyssier, 1992; Kistler, 1993; Greene and Schweickert, 1995; Tikoff and de St. Blanquat, 1997). It is also notable that the MSLF and WNS are trending northward and southward, respectively, toward one another in the vicinity of western Nevada (fig. 1). When considering this relation, it is important to recall that $\sim 70$ to 80 percent east-west extension occurred in the United States Cordillera in the Cenozoic, mostly within the area of Nevada (Gans, 1987; Wernicke, 1992). If this extension is removed (see later discussion and fig. 7), the MSLF and WNS are essentially along strike from one another.

These relations collectively lead to the conclusion that the MSLF and WNS are likely related parts of a single structural zone, extending from southern California to southeast Oregon, that accommodated $\sim 400 \mathrm{~km}$ of dextral strike-slip displacement in the Early Cretaceous followed by contractional or transpressional deformation, localized along and near the older strike-slip boundary, in the mid-Cretaceous during emplacement of Cretaceous plutons and batholiths. All terranes to the west of this zone, including the Klamath Mountains province and the northern and western Sierra terranes, are thus interpreted to have been displaced northward in the Early Cretaceous from an original Jurassic position located $\sim 400 \mathrm{~km}$ to the south. These conclusions are in concert with those put forth originally by Schweickert and Lahren (1990, 1993) and later argued by Wyld, Quinn, and Wright (1996).

Moving to the north, the WNS trends toward the Salmon River suture zone (SRS) in western Idaho (fig. 1). Again, when Cenozoic Basin-and-Range extension is removed, these structural zones are nearly along strike from one another (fig. 7). Most of the intervening area is covered by Cenozoic strata; however, there is a small area in southwest Idaho where plutonic rocks of Late Cretaceous age are exposed (Owyhee County area; OW in fig. 1; Taubeneck, 1971; Ekren and others, 1981). In the western 
part of this area, the plutonic rocks have a steeply-dipping ductile (gneissic) foliation similar to that found along the western edge of the Idaho batholith adjacent to the SRS (Taubeneck, 1971).

As noted earlier, the older history of the SRS is a matter of some dispute. The SRS is currently marked by a wide band of strongly deformed rocks, including mylonites, that generally have a steep foliation and downdip lineation (Lund and Snee, 1988; Strayer and others, 1989; Manduca, Kuntz, and Silver, 1993; Tikoff and others, 2000). Ductile deformation within this zone apparently occurred over a protracted time interval, from at least $110 \mathrm{Ma}$ to $70 \mathrm{Ma}$ and may have begun as early as $130 \mathrm{Ma}$ (Lund and Snee, 1988; Strayer and others, 1989; Selverstone, Wernicke, and Aliberti, 1992; Manduca, Kuntz, and Silver, 1993; Snee and others, 1995). There is a general consensus that structures formed between $\sim 110$ to 70 Ma record reverse-sense, contractional deformation, during emplacement of the Idaho batholith and older plutons of the area, although some component of dextral transpressional deformation has also been inferred for this time frame (Gillaspy and others, 2000). There is further consensus, based on isotopic and lithologic contrasts across the boundary, that the SRS marks a lithospheric-scale suture between oceanic and continental rocks that likely formed by strike-slip faulting at an earlier time, although the inferred time of strike-slip displacement is a matter of dispute and is variably thought to have occurred either in the Late Jurassic or the Early Cretaceous. Lund and Snee (1988) and Snee and others (1995) argue that older structures along the SRS, formed from 130 to $95 \mathrm{Ma}$, reflect dextral transpression, although this conclusion has been disputed by other studies (Selverstone, Wernicke, and Aliberti, 1992; Manduca, Kuntz, and Silver, 1993).

Collectively, these relations are very similar, within the constraints of uncertainties about the early history of the SRS, with the evolution of the WNS. Considered in conjunction with the fact that the SRS and WNS trend toward one another and that an area of ductilely deformed Cretaceous plutons is present in the one area of exposure between these two structural zones (OW; fig. 1), we conclude that the SRS and WNS are likely parts of a single structural boundary that experienced an early strike-slip history, followed by younger localized shortening deformation during emplacement of Cretaceous plutons.

In summary, we conclude that the MSLF system in the Sierra Nevada, the WNS in northwest Nevada and southeast Oregon, and the SRS in western Idaho are all related parts of a single structural boundary in the United States Cordillera that records dextral strike-slip displacement of several $100 \mathrm{~km}$ during the Early Cretaceous (between 150-108 Ma, based on age relations from the MSLF and WNS), followed by reactivation of the strike-slip boundary as a contractional zone in the mid-Cretaceous during emplacement of Cretaceous plutons and batholiths (115-75 Ma). In the following section, we show a restoration of outboard terranes to their inferred pre-strike-slip position and note evidence that supports this reconstruction.

Reconstruction.-Figure 7 shows our preferred pre-Cretaceous reconstruction of terranes of the western United States Cordillera based on the relations we have outlined above. This reconstruction removes Cenozoic extension in the Basin-andRange province and Cretaceous westward displacement of the Klamath Mountains from the Sierra Nevada (Jones and Irwin, 1971). The reconstruction is based on the following. (1) It assumes that the SRS, WNS, and MSLF were all related parts of a dextral strike-slip fault boundary in the Early Cretaceous. This assumption is only meant as a first-order approximation, since it is likely that any large-scale strike-slip system such as this would involve more than a single fault strand. (2) It restores outboard terranes of the Blue Mountain province, Klamath Mountains, and northern and western Sierra terranes to a position $\sim 400 \mathrm{~km}$ south of their current location. This amount of displacement is based on data from the MSLF (Lahren and others, 1990; 


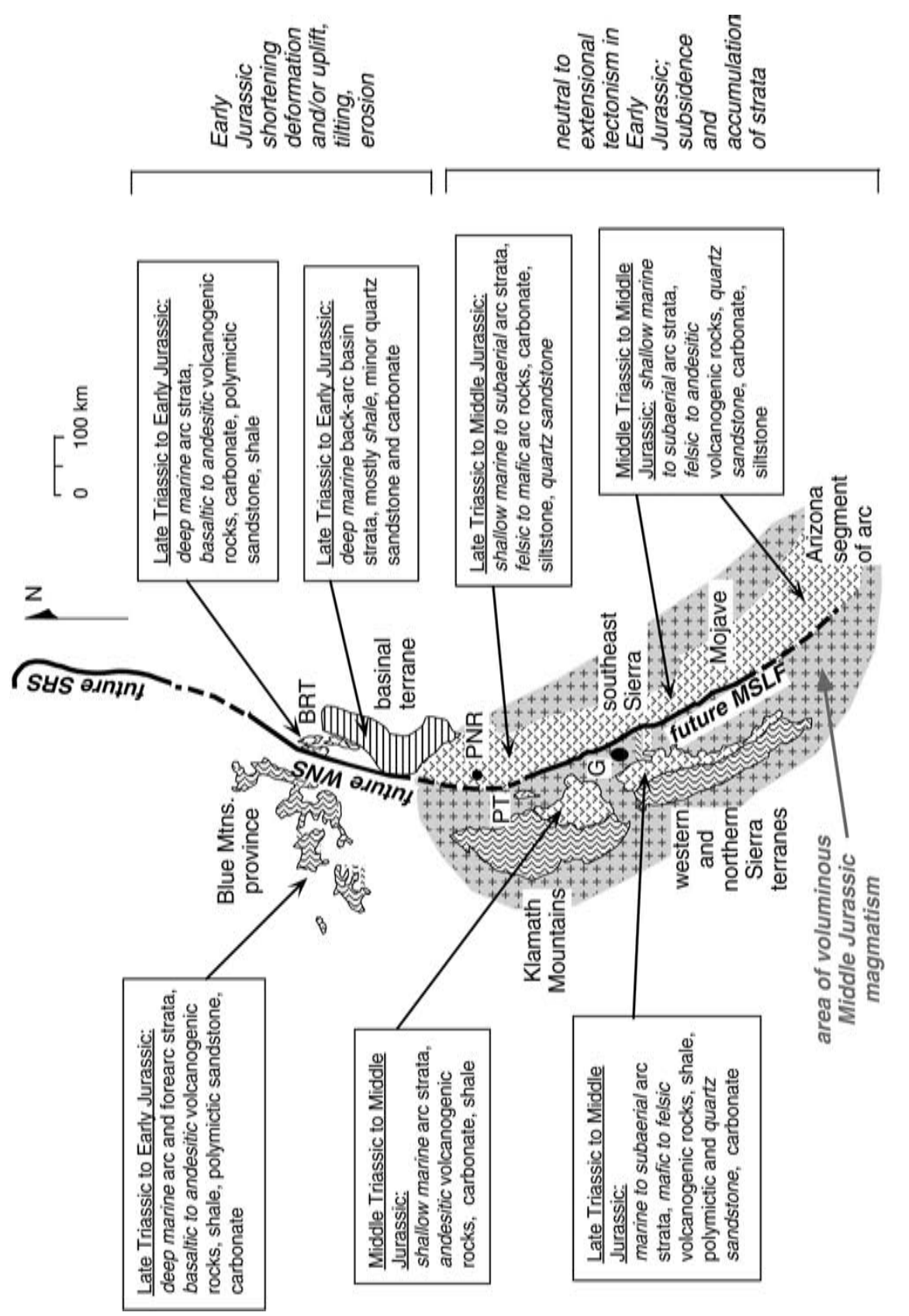

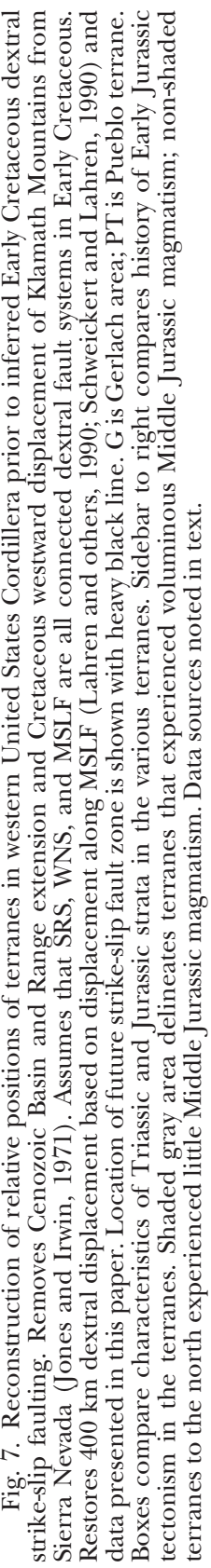


Schweickert and Lahren, 1990, 1993) and from the WNS. (3) It assumes that the Black Rock terrane, basinal terrane, and arc assemblages of west-central Nevada (Pine Nut Range [PNR] and vicinity) have not moved significantly relative to the adjacent continent, based on stratigraphic and detrital zircon data presented in Dilles and Wright (1998), Wyld and Wright (1993), Darby, Wyld, and Gehrels (2000), Manuszak, Satterfield, and Gehrels (2000), and Wyld (2000).

Several relations argue that this reconstruction is more compatable with the early Mesozoic evolution of rock assemblages within this part of the Cordillera than is the current arrangement of terranes. First, the reconstruction juxtaposes, to the north, provinces that experienced Early Jurassic shortening deformation (Blue Mountain province, Black Rock terrane, and basinal terrane; Dickinson and Thayer, 1978; Speed, 1978; White and Vallier, 1994; Vallier, 1995; Wyld, 1996, 2000; Wyld, Quinn, and Wright, 1996; Rogers, ms; Wyld and Wright, 2000a), while juxtaposing, to the south, provinces that experienced neutral to extensional Early Jurassic tectonism (Klamath Mountains, Sierra Nevada, Pine Nut Range and vicinity, and Mojave/Arizona region; Sanborn, 1960; Busby-Spera, 1988; Dilles and Wright, 1988; Harwood, 1992; Saleeby and Busby-Spera, 1992; Wyld and Wright, 1993; Wright and Wyld, 1994). As discussed by Wyld, Quinn, and Wright (1996), this reconstruction makes it far easier to explain plate tectonic controls on Early Jurassic tectonism in the United States Cordillera.

Second, it restores all the intermediate and/or felsic, shallow marine and/or subaerial arc assemblages recognized in outboard terranes (Pueblo terrane, eastern Klamath terrane, parts of the northern Sierra terrane; Sanborn, 1960; Harwood, 1992, 1993; Christe, 1993; Wolak and Wyld, 2000) to a southerly position adjacent to similar continental arc assemblages present from the Pine Nut Range and vicinity to western Arizona (Busby-Spera, 1988; Dilles and Wright, 1988; Saleeby and Busby-Spera, 1992; Wyld and Wright, 1993). It simultaneously restores lower Mesozoic deep marine, mafic to intermediate magmatic arc and related assemblages of the Blue Mountain province (Dickinson and Thayer, 1978; Blome and Nestell, 1991; Vallier, 1995) to a position adjacent to the deep marine lower Mesozoic arc and back-arc assemblages of the Black Rock terrane and basinal terrane (Wyld, 2000). This creates a simpler early Mesozoic paleogeography in the western United States Cordillera (fig. 7).

Finally, it juxtaposes, to the south, areas that experienced voluminous Middle Jurassic magmatism (Pueblo terrane, Klamath Mountains, Sierra Nevada, and arc assemblages from the Pine Nut Range to southwest Arizona; Karish, Miller, and Sutter, 1987; Busby-Spera, 1988; Dilles and Wright, 1988; Sharp, 1988; Wright and Fahan, 1988; Tosdal, Haxel, and Wright, 1989; Wyld and Wright, 1993; Dunne and others, 1998; Wolak and Wyld, 2000), while juxtaposing, to the north, areas that did not experience voluminous Middle Jurassic magmatism (Blue Mountain province and Black Rock terrane; Vallier, 1995; Wyld, 1996; Quinn, Wright, and Wyld, 1997). This again creates a simpler paleogeography, in terms of the location of arc magmatism, for the United States Cordillera (fig. 7).

Influence of the Crustal Boundary on Cretaceous shortening.-The mid-Late Cretaceous was a time of significant shortening deformation in the United States Cordillera. It was during this time frame that the Sevier fold-and-thrust belt developed and that deeperseated deformation within the hinterland of the Sevier belt occurred (fig. 8). Although some shortening in this region occurred in the earliest Cretaceous, most of the shortening within the fold-thrust belt and hinterland occurred from the Albian $(\sim 110$ Ma) to the Paleocene (Lawton, 1985; Heller and others, 1986; Snoke and Miller, 1988; Allmendinger, 1992; Smith and others, 1993; DeCelles, 1994; DeCelles, Lawton, and Mitra, 1995). There is no evidence that this orogenic episode is related to collisional tectonism at the plate margin, and it is instead interpreted to be related to relatively rapid westward motion of the North America plate over the subducting Farallon plate 


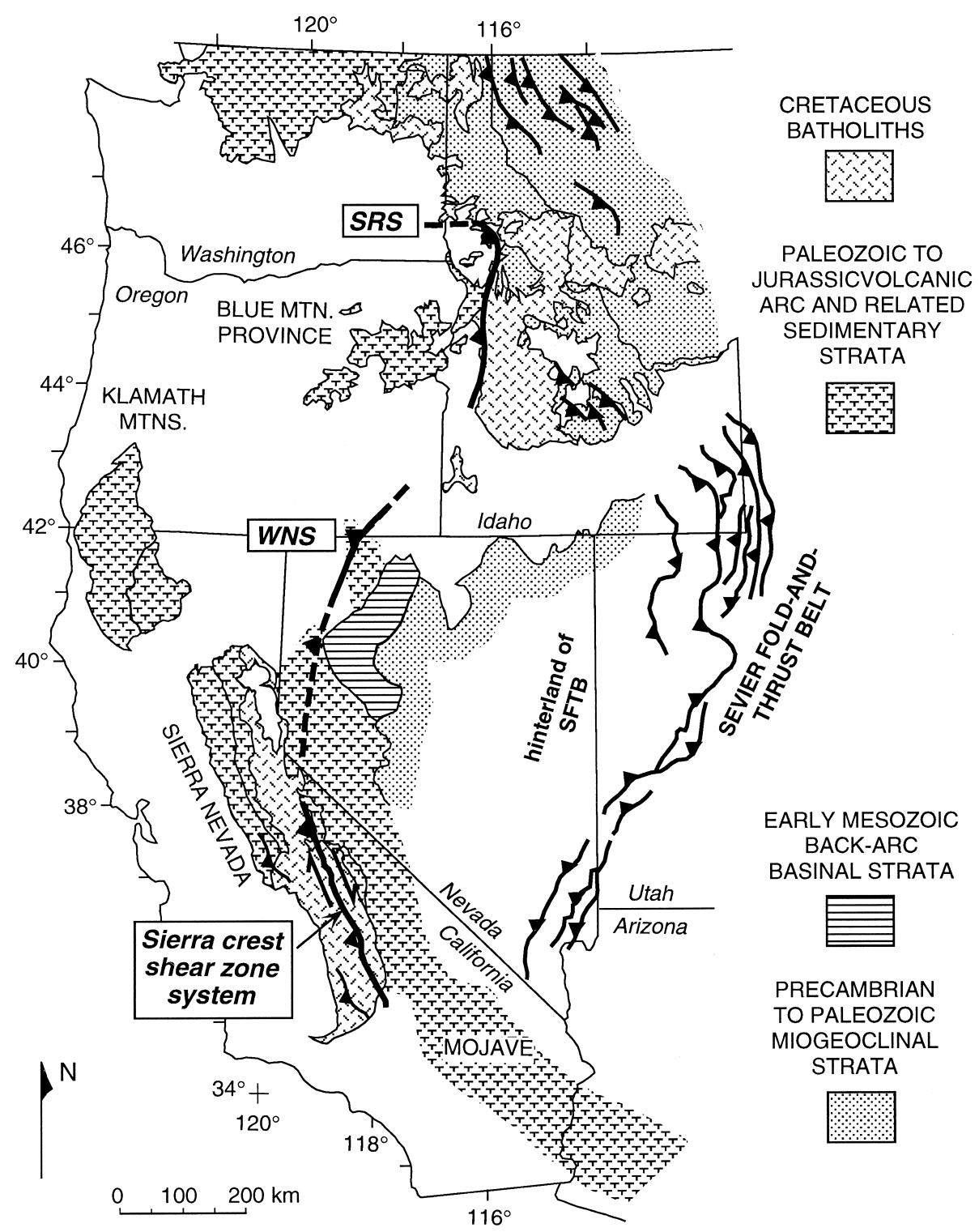

Fig. 8. Principal areas of mid-Cretaceous shortening deformation in the western United States Cordillera, shown in heavy black lines. Transpressional Sierra crest shear zone system from Green and Schweickert (1995) and Tikoff and de St. Blanquat (1997). WNS is western Nevada shear zone, SRS is Salmon River suture zone.

(Engebretson, Cox, and Gordon, 1985; Burchfiel, Cowan, and Davis, 1992; Smith and others, 1993).

Although the driving force for mid-Late Cretaceous orogenesis in the United States Cordillera was subduction along the plate margin located west of the Cretaceous batholithic belts (fig. 8), there is remarkably little evidence for Cretaceous shortening deformation between the Sevier hinterland and the Franciscan complex of western California (Burchfiel, Cowan, and Davis, 1992; Smith and others, 1993). Smith and 
others (1993) have argued that this feature reflects a propagation of the locus of shortening deformation eastward into the continent during the Mesozoic, since most Jurassic shortening deformation in the United States Cordillera occurred in the arc provinces to the west, and most subsequent Cretaceous shortening occurred in the continent to the east. Similar patterns of foreland-migrating deformation are found in other mountain systems (Molnar and Lyon-Caen, 1988).

As shown in figure 8, however, there are some localized areas within the western Cordillera in which significant Cretaceous shortening deformation has been recognized. Within the Sierra Nevada, high strain Cretaceous shortening and/or dextral transpression is recognized in the general area of the MSLF, along and near the Sierra Crest shear zone (Saleeby and others, 1990; Greene and Schweickert, 1995; McNulty, 1995; Tikoff and de Saint Blanquat, 1997), and locally somewhat to the west of this (Saleeby, Sams, and Kistler, 1987; Tobisch and others, 1989), but nowhere else within the province. No Cretaceous shortening is recognized in the Klamath Mountains province (Irwin, 1981; Wright and Fahan, 1988). Within western Nevada, Cretaceous shortening strain is minor and tends to be localized in Cretaceous pluton aureoles, except along and near the WNS where high strain shortening is recognized (Smith and others, 1993; Wyld, ms, and 1996, 1998; Wyld and Wright, 1993; Quinn, Wright, and Wyld, 1997; Rogers, ms; Wolak and Wyld, 2000; Wyld and Wright, 2000a; this paper). Finally, in the eastern Oregon-western Idaho part of the Cordillera, high strain Cretaceous shortening is recorded by structures along and near the SRS (Lund and Snee, 1988; Strayer and others, 1989; Manduca, Kuntz, and Silver, 1993; Snee and others, 1995), but nowhere else. These relations indicate that Cretaceous shortening within the arc region of the United States Cordillera was localized along the MSLF-WNSSRS zone. The timing of shortening deformation along this zone is generally $\sim 110$ to $80 \mathrm{Ma}$ in the Sierra Nevada, $\sim 115$ to $108 \mathrm{Ma}$ in northwestern Nevada, and 110 to $70 \mathrm{Ma}$ in western Idaho. These ages are consistent with the timing of early deformation within the Sevier fold-thrust belt and hinterland, suggesting that shortening deformation along this zone is most likely related to the Sevier orogeny.

Localization of Sevier-age Cretaceous shortening within the arc region along the MSLF-WNS-SRS zone is highly unusual in view of the general lack of Cretaceous shortening elsewhere within this part of the Cordillera. We propose, therefore, that Cretaceous shortening was localized along this trend because there was a pre-existing zone of weakness within the crust in this region. The only other possible explanation for the restricted location of Cretaceous shortening deformation in the western Cordillera is that shortening was facilitated in the thermally softened part of the crust near the Cretaceous arc axis. This possibility is not robust, however, because most of the Cretaceous plutonic belt is undeformed. We conclude, therefore, that the restricted location of Sevier-age Cretaceous shortening in the arc region of the United States Cordillera is related to the existence of a prior zone of weakness in the crust of this area. Based on the evidence for older strike-slip faulting along the MSLF-WNS-SRS crustal boundary, we argue that the prior zone of weakness was this strike-slip system. Our interpretation is that mid-Late Cretaceous shortening during the Sevier orogeny reactivated the older strike-slip boundary as a contractional zone, whereas other parts of the arc and back-arc areas within the western Cordillera not cut by this older crustal flaw were likewise not affected by significant shortening deformation. This conclusion is consistent with relations described for the WNS; and Manduca, Kuntz, and Silver (1993), Tikoff and others (2000), and Greene and Schweickert (1995) have drawn similar conclusions for the localization of Cretaceous shortening within western Idaho and the Sierra Nevada.

Influence of the Crustal Boundary on Cretaceous arc magmatism.-There is also convincing evidence that the MSLF-WNS-SRS strike-slip boundary localized the emplacement 


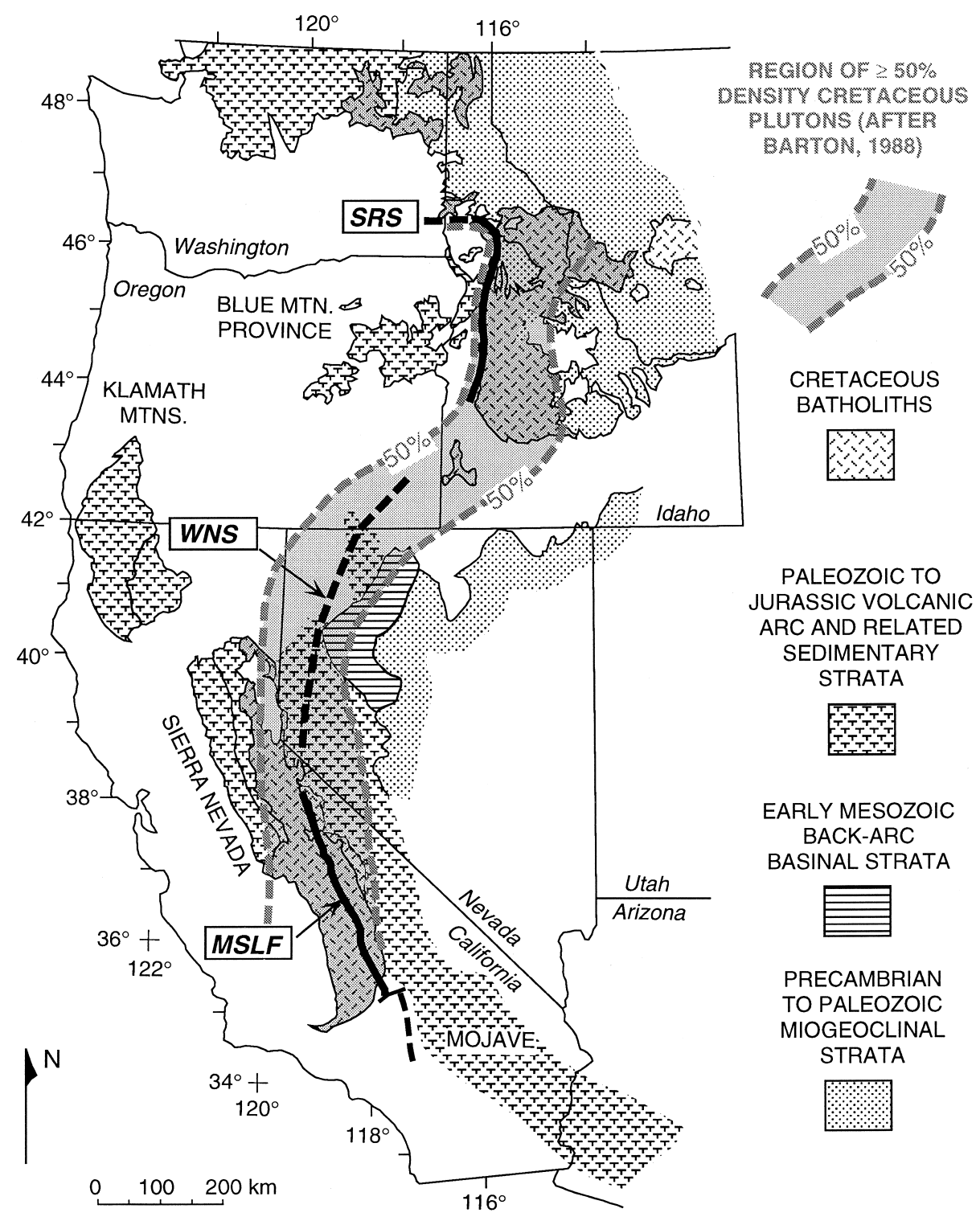

Fig. 9. Location of greatest abundance of mid-Cretaceous plutons (after Barton and others, 1988) relative to location of Mojave-Snow Lake fault (MSLF), western Nevada shear zone (WNS), and Salmon River suture zone (SRS).

of younger mid-Late Cretaceous arc magmas. Barton and others (1988) determined the relative areal abundance of Cretaceous plutons in the United States Cordillera; figure 9 shows the region in which they calculate that there are $>50$ percent Cretaceous plutons. This region includes the Sierra Nevada and Idaho batholiths, as well as northwest Nevada where large Cretaceous plutons are abundant (fig. 2) but not visibly of batholithic scale due to the presence of substantial Cenozoic cover related to Basin-and-Range extension. The MSLF-WNS-SRS crustal boundary is also shown in figure 9. It is evident from this figure and figure 2 that there is a remarkable spatial 
correlation between the area of greatest abundance of mid-Late Cretaceous plutons and the MSLF-WNS-SRS strike-slip boundary. We propose, therefore, that this older subvertical crustal flaw served as an easy pathway for upward migration of younger arc magmas and thus controlled, at least in part, the location of this plutonic belt within the United States Cordillera. Broadly similar conclusions have been drawn about the location of Cretaceous arc plutons in the Sierra Nevada and western Idaho, relative to the location of the MSLF and SRS (Lahren and others, 1990; Greene and Schweickert, 1995; Snee and others, 1995).

SUMMARY AND CONLUSIONS

The principal conclusions we have drawn in this paper are as follows.

1. A major terrane boundary, herein called the western Nevada shear zone (WNS), extends from the Pueblo Mountains in southeast Oregon to the Gerlach area of western Nevada. This terrane boundary separates rock assemblages that have no obvious relation to one another and records dextral strike-slip displacement of terranes to the west of the boundary from an original location several $100 \mathrm{~km}$ farther to the south. Strike-slip displacement occurred in the Early Cretaceous, prior to $108 \mathrm{Ma}$ and most likely between 140 to $120 \mathrm{Ma}$. The WNS was then reactivated as a contractional boundary in the mid-Cretaceous during emplacement of 115 to 108 Ma plutons. This reactivation led to development of the dip-slip, reverse-sense ductile shear zones that now characterize the boundary.

2. The two-part evolution of the WNS is very similar to that of fault zones within the southern Sierra Nevada, including the Mojave-Snow Lake fault (MSLF) and Sierra Crest shear zone system, and to that of the Salmon River suture zone (SRS) in western Idaho. All of these structural boundaries lie essentially along strike from one another when Cenozoic extension is restored. We argue, therefore, that the MSLF, WNS, and SRS all represent related parts of a single $>1000 \mathrm{~km}$ long structural boundary in the United States Cordillera that accommodated several $100 \mathrm{~km}$ of dextral strike-slip displacement in the Early Cretaceous, followed by reactivation of the strike-slip boundary as a contractional zone in the mid-Cretaceous during emplacement of Cretaceous arc plutons.

3. The combined MSLF-WNS-SRS strike-slip boundary served as a major crustal flaw in the United States Cordillera that localized and facilitated younger mid-Late Cretaceous shortening related to the Sevier orogeny in this part of the Cordillera and that helped control the emplacement location of younger mid-Late Cretaceous arc magmas.

Two additional interesting conclusions can be drawn from this study. First, the relations we describe in this paper suggest that a major strike-slip boundary like the MSLF-WNS-SRS can be reactivated during later shortening deformation, thereby obscuring evidence of older strike-slip structural relations (see also Tikoff and others, 2000) and can also serve as a pathway for later magmatism which may intrude across the older boundary. These two younger processes can make it difficult to recognize the older strike-slip history of the boundary. This conclusion has implications for other studies that seek to find evidence for cryptic strike-slip tectonic boundaries within orogenic belts and emphasizes the need for caution in interpreting the kinematic history of tectonic boundaries that may have served as a locus for later magmatism and shortening deformation.

Second, the data we describe indicate that outboard terranes of the United States Cordillera are not currently located in the position, relative to the continental margin, that they occupied prior to the Early Cretaceous. In particular, we conclude that all terranes outboard of the MSLF-WNS-SRS, including the Blue Mountain province, the 
Klamath Mountains, and the northern and western Sierra terranes, originated several $100 \mathrm{~km}$ to the south prior to strike-slip displacement in the Early Cretaceous. This conclusion has significant implications for pre-Cretaceous paleogeographic and tectonic reconstructions and supports the conclusions of numerous other studies that strike-slip displacement of outboard terranes has been an important process in the North American Cordillera.

\section{ACKNOWLEDGMENTS}

This project was supported by National Science Foundation grants EAR-9796174, EAR-9814356, and EAR-9814308. It has benefited from discussions with Chad Wolak, Bernard Housen, Richard Schweickert, and Basil Tikoff, as well as numerous other people, including many who attended the 1999 Penrose Conference on "Terrane Accretion along the Western Cordilleran Margin: Constraints on Timing and Displacement" and the 1999 Terrane Paths conference in Canada. Comments and reviews by Bill McClelland and Darrel Cowan were very helpful and improved the final version of the paper.

\section{REFERENCES}

Allmendinger, R. W., 1992, Fold and thrust tectonics of the western United States exclusive of the accreted terranes, in Burchfiel, B. C., Lipman, P. W., and Zoback, M. L., editors, The Cordilleran Orogen: Conterminous United States: Boulder, Colorado, Geological Society of America, The Geology of North America, v. G-3, p. 583-608.

Armstrong, R. L., 1968, Sevier orogenic belt in Nevada and Utah: Geological Society of America Bulletin, v. 79 , p. $429-458$.

Armstrong, R.L., Taubeneck, W.H., and Hales, P.O., 1977, Rb-Sr and K-Ar geochronometry of Mesozoic granitic rocks and their $\mathrm{Sr}$ isotopic composition: Oregon, Washington, and Idaho: Geological Society of America Bulletin, v. 88, p. 397-411.

Ave Lallemant, H. G., and Oldow, J. S., 1988, Early Mesozoic southward migration of Cordilleran transpressional terranes: Tectonics, v. 7, p. 1057-1076.

Barton, M. D., Battles, D. A., Bebout, G. E., Capo, R. C, Christianson, J. N., Davis, S. R., Hanson, R. B., Michelson, C. J., and Trim, H, E, 1988, Mesozoic contact metamorphism in the western United States, in Ernst, W. G., editor, Metamorphism and crustal evolution, western coterminous United States, Rubey Volume 7: Englewood Cliffs, New Jersey, Prentice-Hall, p. 111-178.

Bassett, K. N., and Kleinspehn, K., L, 1996, Mid-Cretaceous transtension in the Canadian Cordillera: Evidence from the Rocky Ridge volcanics of the Skeena Group: Tectonics, v. 15, p. 727-746.

Beck, M. E. Jr., 1976, Discordant paleomagnetic pole positions as evidence of regional shear in the western Cordillera of North America: American Journal of Science, v. 276, p. 694-712.

- 1983, On the mechanism of tectonic transport in zones of oblique subduction: Tectonophysics, v. 93, p. $1-11$.

Beck, M. E. Jr., Burmeister, R. F., and Schoonover, R., 1981, Paleomagnetism and tectonics of the Cretaceous Mt. Stuart Batholith of Washington: Translation or tilt?: Earth and Planetary Science Letters, v. 56, p. 336-342.

Blome, C. D., and Nestell, M. K., 1991, Evolution of a Permo-Triassic sedimentary melange, Grindstone terrane, east-central Oregon: Geological Society of America Bulletin, v. 103, p. 1280-1296.

Boettcher, S. S., and Walker, J. D., 1993, Geologic evolution of Iron Mountain, central Mojave Desert, California: Tectonics, v. 12, p. 372-386.

Bonham, H. F., 1969, Geology and mineral deposits of Washoe and Storey Counties, Nevada: Nevada Bureau of Mines and Geology Bulletin 70, $140 \mathrm{pp}$.

Brown, M. A., ms, 1996, The pre-Tertiary geology, structural evolution, and geochronology of the Pueblo Mountains, Nevada-Oregon: M.S. thesis, Rice University, Houston, Texas, 78 p.

Burchfiel, B. C., Cowan, D. S., and Davis, G. A., 1992, Tectonic overview of the Cordilleran orogen in the western United States, in Burchfiel, B. C., Lipman, P. W., and Zoback, M. L. editors, The Cordilleran Orogen: Conterminous United States: Boulder, Colorado, Geological Society of America, The Geology of North America, v. G-3, p. 407-479.

Busby-Spera, C. J., 1988, Speculative tectonic model for the early Mesozoic arc of the southwest Cordilleran United States: Geology, v. 16, p. 1121-1125.

Busby-Spera, C. J., and Saleeby, J. B., 1990, Intra-arc strike-slip fault exposed at batholithic levels in the southern Sierra Nevada, California: Geology, v. 18, p. 255-259.

Chen, J. H., and Moore, J. G., 1982, Uranium-lead isotopic ages from the Sierra Nevada batholith, California: Journal of Geophysical Research, v. 87, p. 4761-4784.

Christe, G., 1993, The stratigraphy and depositional environments of Jurassic volcanic and volcaniclastic rocks of the Kettle Rock sequence north of $40^{\circ} \mathrm{N}$ latitude, in Dunne, G., and McDougall, K., editors, Mesozoic Paleogeography of the western United States-II: Los Angeles, California, Society of Economic Paleontologists and Mineralogists, Pacific Section, Book 71, p. 275-288. 
Cowan, D. S., Brandon, M. T., and Garver, J. I, 1997, Geologic tests of hypotheses for large coastwise displacements - a critique illustrated by the Baja British Columbia controversy: American Journal of Science, v. 297, p. 117-173.

Criss, R.E., and Fleck, R.J., 1987, Petrogenesis, geochronology, and hydrothermal systems of the northern Idaho batholith and adjacent areas based on ${ }^{18} \mathrm{O} /{ }^{16} \mathrm{O}, \mathrm{D} / \mathrm{H},{ }^{87} \mathrm{Sr} /{ }^{86} \mathrm{Sr}, \mathrm{K}-\mathrm{Ar}$, and ${ }^{40} \mathrm{Ar} /{ }^{39} \mathrm{Ar}$ studies, in Vallier, T.L., and Brooks, H. C., editors, Geology of the Blue Mountains region of Oregon, Idaho, and Washington: the Idaho batholith and its border zone: United States Geological Survey Professional Paper 1436, p. 95-138.

Cross, T. A., and Pilger, R. H., Jr., 1982, Controls of subduction geometry, location of magmatic arcs, and tectonics of arc and back-arc regions: Geological Society of America Bulletin, v. 93, p. 545-562.

Darby, B. J., Wyld, S. J., and Gehrels, G. E., 2000, Provenance and paleogeography of the Black Rock terrane northwestern Nevada: Implications of U-Pb detrital zircon geochronology, in Soreghan, M. J., and G. E. Gehrels, editors, Paleozoic and Triassic paleogeography and tectonics of western Nevada and northern California: Geological Society of America Special Paper 347, p. 77-87.

DeCelles, P. G., 1994, Late Cretaceous-Paleocene synorogenic sedimentation and kinematic history of the Sevier thrust belt, northeast Utah and southwest Wyoming: Geological Society of America Bulletin, v. 106, p. 32-56.

DeCelles, P. G., Lawton, T. F., and Mitra, G., 1995, Thrust timing, growth of structural culminations, and synorogenic sedimentation in the type Sevier orogenic belt, western United States: Geology, v. 23, p. 699-702.

Dewey, J. F., 1980, Episodicity, sequence, and style at convergent plate boundaries: Geological Association of Canada Special Paper, v. 20, p. 553-573.

Dewey, J. F., Holdsworth, R. E., and Strachan, R. A., 1998, Transpression and transtension zones, in Holdsworth, R. D., Strachan, R. A., and Dewey, J. F., editors, Continental Transpressional and Transtensional Tectonics: Geological Society of London, Special Publications, v. 135, p. 1-14.

Dickinson, W. R., and Thayer, T. P., 1978, Paleogeogprahic and paleotectonic implications of Mesozoic stratigraphy and structure in the John Day inlier of central Oregon, in Howell, D. G., and McDougall, K. A., editors, Mesozoic paleogeography of the western United States: Society of Economic Paleontologists and Mineralogists, Pacific Section, Pacific Coast Paleogeography Symposium 2 , p. 147-161.

Dilles, J. H., and Wright, J. E., 1988, The chronology of Early Mesozoic arc magmatism in the Yerington district of western Nevada, and its regional implications: Geological Society of America Bulletin, v. 100, p. $644-652$.

Dunne, G. C., Garvey, T. P., Oborne, M., Schneidereit, D., Fritsche, A. E., and Walker, J. D., 1998, Geology of the Inyo Mountains volcanic complex: Implications for Jurassic paleogeography of the Sierran magmatic arc in eastern California: Geological Society of America Bulletin, v. 110, p. 1376-1397.

Dunne, G. C., and Walker, J. D, 1993, Age of Jurassic volcanism and tectonism, southern Owens Valley region, east-central California: Geological Society of America Bulletin, v. 105, p. 1223-1230.

Dutton, B. J., 1997, Finite strains in transpression zones with no boundary slip: Journal of Structural Geology, v. 19 , p. $1189-1200$.

Ekren, E. E., McIntyre, D. H., Bennett, E. H., and Malde, H. E., 1981, Geological map of Owyhee County, Idaho west of longitude $116^{\circ} \mathrm{W}$ : United States Geological Survey, Miscellaneous Investigations Series Map I-1256.

Elison, M. W., and Speed, R. C., 1989, Structural development during flysch basin collapse: the Fencemaker allochthon, East Range, Nevada: Journal of Structural Geology, v. 11, p. 523-538.

Engebretson, D. C., Cox, A., and Gordon, R. G., 1985, Relative motions between oceanic and continental plates in the Pacific basin: Geological Society of America Special Paper 206, 59 p.

Fossen, H., and Tikoff, B., 1993, The deformation matrix for simultaneous simple shearing, pure shearing and volume change, and its application to transpression-transtension tectonics: Journal of Structural Geology, v. 15, p. 413-422.

Fossen, H., Tikoff, B., and Teyssier, C., 1994, Strain modeling of transpressional and transtensional deformation: Norsk Geologisk Tidsskrift, v. 74, p. 134-145.

Gabrielse, H., 1985, Major dextral transcurrent displacements along the Northern Rocky Mountain Trench and related lineaments in north-central British Columbia: Geological Society of America Bulletin, v. 96, p. 1-14.

Gabrielse, H., and Yorath, C. J., 1991, Tectonic synthesis, Chapter 18, in Gabrielse, H. and Yorath, C. J., editors, Geology of the Cordilleran Orogen in Canada: Geological Survey of Canada, Geology of Canada, no. 4, p. 677-705.

Gans, P. B., 1987, An open-system, two-layer crustal stretching model for the eastern Great Basin: Tectonics, v. 6 , p. $1-12$.

Gianella, V.P., and Larson, E.R., 1960, Marine Permian at Black Rock, Nevada: Geological Society of America Bulletin, v. 71, p. 2061.

Gill, J. B., 1981, Orogenic andesites and plate tectonics: Springer-Verlag, Berlin, Heidelberg, New York, $390 \mathrm{p}$.

Gillaspy, J., Tikoff, B., Kolker, A., and Wojtal, S., 2000, Transpressional fabric in orthogneiss of the western Idaho shear zone, Idaho: Geological Society of America Abstracts with Programs, v. 32, no. 7, p. A-99.

Girty, G. H., Yoshinobu, A. S., Wracher, M. D., Girty, M. S., Bryan, K. A., Skinner, J. E., McNulty, B. A., Bracchi, K. A., Harwood, D. S., and Hanson, R. E., 1993, U-Pb zircon geochronology of the Emigrant Gap composite pluton, northern Sierra Nevada, California: Implications for the Nevadan orogeny, in Dunne, G., and McDougall, K., editors, Mesozoic Paleogeography of the western United States-II: Los Angeles, California, Society of Economic Paleontologists and Mineralogists, Pacific Section, Book 71, p. 323-332. 
Glazner, A. F., Bartley, J. M., and Carl, B. S., 1999, Oblique opening and noncoaxial emplacement of the Jurassic Independence dike swarm, California: Journal of Structural Geology, v. 21, p. 1275-1283.

Greene, D. C., and Schweickert, R. A., 1995, The Gem Lake shear zone: Cretaceous dextral transpression in the northern Ritter Range pendant, eastern Sierra Nevada, California: Tectonics, v. 14, p. 945-961.

Harper, G. D., Saleeby, J. B., and Norman, E. A. S., 1985, Geometry and tectonic setting of sea-floor spreading for the Josephine ophiolite, and implications for Jurassic accretionary events along the California margin, in Howell, D. G., editor, Tectonostratigraphic terranes of the circum-Pacific region: Houston, Texas, Circum-Pacific Council for Energy and Mineral Resources, Earth Science Series no. 1, p. 239-257.

Harper, G.D., and Wright, J.E., 1984, Middle to Late Jurassic tectonic evolution of the Klamath Mountains, California-Oregon: Tectonics, v.3, p. 759-772.

Harwood, D. S., 1992, Stratigraphy of Paleozoic and lower Mesozoic rocks in the northern Sierra terrane, California: U. S. Geological Survey Bulletin 1957, 78 pp.

_ 1993, Mesozoic geology of Mt. Jura, northern Sierra Nevada, California: A progress report, in Dunne, G., and McDougall, K., editors, Mesozoic Paleogeography of the western United States-II: Los Angeles, California, Society of Economic Paleontologists and Mineralogists, Pacific Section, Book 71, p. 263-274.

Heller, P. L., Bowdler, S. S., Chambers, H. P., Coogan, J. C., Hagen, E. S., Shuster, M. W., Winslow, N. S., and Lawton, T. F., 1986, Time of initial thrusting in the Sevier Orogenic belt, Idaho-Wyoming and Utah: Geology, v. 14, p. 388-391.

Hollister, L. S., and Andronicos, C. L., 1997, A candidate for the Baja British Columbia fault system in the Coast Plutonic Complex: GSA Today, v. 7, no. 11, p. 1-7.

Irving, E., 1985, Whence British Columbia?: Nature, v. 314, p. 673-674.

Irving, E., and Wynne, P. J., 1990, Paleomagnetic evidence bearing on the evolution of the Canadian Cordillera: Philosophical Transactions of the Royal Society of London, v. A331, p. 487-509.

Irving, E., Wynne, P. J., Thorkelson, D. J., and Schiarizza, P., 1996, Large (1000 to $4000 \mathrm{~km}$ ) northward movements of tectonic domains in the Northern Cordillera, 83-45 Ma: Journal of Geophysical Research,v. 101, p. 17901-17916.

Irwin, W.P., 1981, Tectonic accretion of the Klamath Mountains, in Ernst, W.G., editor, The Geotectonic Development of California, Rubey Volume 1: Englewood Cliffs, New Jersey, Prentice-Hall, p. $29-49$.

Jarrard, R. D., 1986, Terrane motion by strike-slip faulting of forearc slivers: Geology, v. 14, p. 780-783.

Jayko, A. S., and Blake, M. C., Jr., 1993, Northward displacements of forearc slivers in the Coast Range of California and southwest Oregon during the late Mesozoic and early Cenozoic, in Dunne, G., and McDougall, K., editors, Mesozoic Paleogeography of the western United States-II: Los Angeles, California, Society of Economic Paleontologists and Mineralogists, Pacific Section, Book 71, p. 19-36.

Johnson, M. G., 1974, Geology and mineral deposits of Pershing County, Nevada: Nevada Bureau of Mines and Geology Bulletin 89, 115 p.

Jones, A. E., 1990, Geology and tectonic significance of terranes near Quinn River Crossing, Humboldt County, Nevada, in Harwood, D. S., and Miller, M. M., editors, Paleozoic and Early Mesozoic Paleogeographic Relations; Sierra Nevada, Klamath Mountains, and Related Terranes: Geological Society of America Special Paper 255, p. 239-254.

Jones, D.L., and Irwin, W.P., 1971, Structural implications of an offset Early Creataceous shoreline in Northern California: Geological Society of America Bulletin, v.82, p. 815-822.

Karish, C. R., Miller, E. L., and Sutter, J. F., 1987, Mesozoic tectonic and magmatic history of the central Mojave Desert, in Dickinson, W., and Klute, M., editors, Mesozoic rocks of southern Arizona and adjacent regions: Arizona Geological Society Digest, v. 18, p. 15-32.

Ketner, K. B., and Wardlaw, B. R., 1981, Permian and Triassic rocks near Quinn River Crossing, Humboldt county, Nevada: Geology, v. 9, p. 123-126.

Kistler, R. W., 1993, Mesozoic intrabatholithic faulting, Sierra Nevada, California, in Dunne, G., and McDougall, K., editors, Mesozoic Paleogeography of the western United States-II: Los Angeles, California, Society of Economic Paleontologists and Mineralogists, Pacific Section, Book 71, p. 247-261

Lahren, M.M., Schweickert, R.A., Mattinson, J.M., and Walker, J.D., 1990, Evidence of uppermost Proterozoic to Lower Cambrian miogeoclinal rocks and the Mojave-Snow Lake fault: Snow Lake pendant, central Sierra Nevada, California: Tectonics, v. 9, p. 1585-1608.

Lawton, T. F., 1985, Style and timing of frontal structures, thrust belt, central Utah: American Association of Petroleum Geologists Bulletin, v. 69, 1145-1159.

Lund, K., ms, 1984, Tectonic history of a continent-island arc boundary: west-central Idaho: Ph.D. dissertation; Pennsylvania State University, University Park, Pennsylvania.

Lund, K., and Snee, L.W., 1988, Metamorphism, structural development, and age of the continent-island arc juncture in west-central Idaho in Ernst, W. G., editor, Metamorphism and crustal evolution, western coterminous United States, Rubey Volume 7: Englewood Cliffs, New Jersey, Prentice-Hall, p. 296-331.

Lupe, R., and Silberling, N. J., 1985, Genetic relationship between lower Mesozoic continental strata of the Colorada Plateau and marine strata of the western Great Basin: significance for accretionary history of Cordilleran lithotectonic terranes: in Howell, D. G., editor, Tectonostratigraphic terranes of the Circum-Pacific region: Circum-Pacific Council for Energy and Mineral Resources, Earth Science Series, no. 1, p. 263-271.

Manduca, C. A., Kuntz, M. A., and Silver, L. T., 1993, Emplacement and deformation history of the western margin of the Idaho batholith near McCall, Idaho: influence of a major terrane boundary: Geological Society of America Bulletin, v. 105, p. 749-765.

Manuszak, J. D., Satterfield, J. I., and Gehrels, G. E., 2000, Detrital zircon geochronology of Upper Triassic strata in western Nevada, in Soreghan, M. J., and Gehrels, G. E., editors, Paleozoic and Triassic paleogeography and tectonic evolution of western Nevada and northern California: Geological Society of America Special Paper 347, p. 109-118. 
McClay, K. R., 1992, Thrust Tectonics: London, Chapman and Hall, 337 p.

McNulty, B. A., 1995, Shear zone development during magmatic arc construction: The Bench Canyon shear zone, central Sierra Nevada, California: Geological Society of America Bulletin, v. 107, p. 1094-1107.

Miller, M. M., and Harwood, D. S., 1990, Stratigraphic variation and common provenance of upper Paleozoic rocks in the northern Sierra and eastern Klamath terranes, northern California, in Harwood, D. S., and Miller, M. M., editors, Paleozoic and Early Mesozoic Paleogeographic Relations; Sierra Nevada, Klamath Mountains, and Related Terranes: Geological Society of America Special Paper 255, p. 175-192.

Molnar, P. and Lyon-Caen, H., 1988, Some simple physical aspects of the support, structure and evolution of mountain belts, in Clark S. P., Jr., Burchfiel, B. C., and Suppe, J., editors, Processes in continental lithospheric deformation: Geological Society of America Special Paper 218, p. 179-207.

Monger, J. W. H., Wheeler, J. O., Tipper, H. W., Gabrielse, H., Harms, T., Struik, L. C., Campbell, R. B., Dodds, C. J., Gehrels, G. E., and O'Brien, J., 1991, Part B. Cordilleran terranes, in Upper Devonian to Middle Jurassic assemblages, Chapter 8, in Gabrielse, H. and Yorath, C. J., editors, Geology of the Cordilleran Orogen in Canada: Geological Survey of Canada, Geology of Canada, no. 4, p. 281-327.

Newton, M. C., III, 1986, Late Jurassic left-lateral transpression along the western North American margin, with structural evidence from the southern Foothills terrane, Sierra Nevada, California: Geological Society of America Abstracts with Programs, v. 18, p. 706.

Oldow, J. S., 1984, Evolution of a late Mesozoic back-arc fold and thrust belt, northwestern Great Basin, U. S. A.: Tectonophysics, v. 102, p. 245-274.

Oldow, J. S., Bally, A. W., Ave Lallemant, H. G., and Leeman, W. P., 1989, Phanerozoic evolution of the North American Cordillera; United States and Canada, in Bally, A. W., and Palmer, A. R., editors, The Geology of North America - An overview: Boulder, Colorado, Geological Society of America, The Geology of North America, v. A, p. 139-232.

Passchier, C. W., 1997, The fabric attractor: Journal of Structural Geology, v. 19, p. 113-127. 1998, Monoclinic model shear zones: Journal of Structural Geology, v. 20, p. 1121-1137.

Quinn, M.J., ms, 1996, Pre-Tertiary stratigraphy, magmatism, and structural history of the central Jackson Mountains, Humboldt County, Nevada: Ph.D. dissertation, Rice University, Houston, Texas, 243 p.

Quinn, M.J., Wright, J.E., and Wyld, S.J., 1997, Happy Creek igneous complex and tectonic evolution of the early Mesozoic arc in the Jackson Mountains, northwest Nevada: Geological Society of America Bulletin, v. 109 , p. $461-482$.

Roback, R. C., Vander Meulen, D. B., King, H. D., Plouff, D., Munts, S. R., and Willett, S. L., 1987, Minera Resources of the Pueblo Mountains Wilderness Study Area, Harney County, Oregon, and Humboldt County, Nevada: U. S. Geological Survey Bulletin 1740, p. B1-B30.

Rogers, J. W., ms, 1999, Jurassic-Cretaceous deformation in the Santa Rosa Range, Nevada: Implications for the developement of the northern Luning-Fencemaker fold-and-thrust belt: M.S. thesis, University of Georgia, Athens, 195 p.

Russell, B. J., 1984, Mesozoic geology of the Jackson Mountains, northwestern Nevada: Geological Society of America Bulletin, v. 95, p. 313-323.

Saleeby, J. B., and Busby-Spera, C., 1992, Early Mesozoic tectonic evolution of the western United States Cordillera, in Burchfiel, B. C., Lipman, P. W., and Zoback, M. L. editors, The Cordilleran Orogen: Conterminous United States: Boulder, Colorado, Geological Society of America, The Geology of North America, v. G-3, p. 107-168.

Saleeby, J. B., Kistler, R. W., Longiaru, S., Moore, J. G., and Nokleberg, W. J., 1990, Middle Cretaceous silicic metavolcanic rocks in the Kings Canyon area, central Sierra Nevada, California, in Anderson, J. L., editor, The nature and origin of Cordilleran magmatism: Geological Society of America Memoir 174, p. 251-270.

Saleeby, J. B., Sams, D. B., and Kistler, R. W., 1987: U/Pb zircon, strontium, and oxygen isotopic and geochronological study of the southernmost Sierra Nevada batholith, California: Journal of Geophysical Research, v. 92, p. 10442-10466.

Sanborn, A. F., 1960, Geology and paleontology of the southwest quarter of the Big Bend quadrangle, Shasta county, California: California Division of Mines and Geology, Special Report 6, 26 p.

Sanderson, D. J., and Marchini, W. R. D., 1984, Transpression: Journal of Structural Geology, v. 6, p. $449-458$.

Schweickert, R. A., 1978, Triassic and Jurassic paleogeography of the Sierra Nevada and adjacent region, California and western Nevada, in Howell, D. G., and McDougall, K. A., editors, Mesozoic paleogeography of the western United States: Society of Economic Paleontologists and Mineralogists, Pacific Section, Pacific Coast Paleogeography Symposium 2 , p. 361-384.

Schweickert, R. A., and Lahren, M. M., 1990, Speculative reconstruction of the Mojave-Snow Late fault: Implications for Paleozoic and Mesozoic orogenesis in the western United States: Tectonics, v. 9, p. $1609-1629$.

1993, Triassic-Jurassic magmatic arc in eastern California and western Nevada: Arc evolution, cryptic tectonic breaks, and significance of the Mojave-Snow Lake fault, in Dunne, G., and McDougall, K., editors, Mesozoic Paleogeography of the western United States-II: Los Angeles, California, Society of Economic Paleontologists and Mineralogists, Pacific Section, Book 71, p. 227-246.

Selverstone, J., Wernicke, B., and Aliberti, E., 1992, Intracontinental subduction and hinged uplift along the Salmon River suture zone in west central Idaho: Tectonics, v. 11, p. 355-372.

Sharp, W. D., 1988, Pre-Cretaceous crustal evolution in the Sierra Nevada region, California in Ernst, W. G., editor, Metamorphism and crustal evolution, western coterminous United States, Rubey Volume 7: Englewood Cliffs, New Jersey, Prentice-Hall, p. 824-864. 
Smith, D. L., Wyld, S. J., Wright, J. E., and Miller, E. L., 1993, Progession and timing of Mesozoic crustal shortening in the northern Great Basin, western U. S. A., in Dunne, G., and McDougall, K., editors, Mesozoic Paleogeography of the western United States-II: Los Angeles, California, Society of Economic Paleontologists and Mineralogists, Pacific Section, Book 71, p. 389-406.

Smith, J. G., ms, 1966, Petrology of the southern Pine Forest Range, Humboldt County, Nevada Ph. D. thesis: Stanford University, Stanford, California, $136 \mathrm{p.}$

_ 1973, Geologic map of the Duffer Peak quadrangle, Humboldt County, Nevada: United States Geological Survey Miscellaneous Field Investigations Map I-606, 1:48,000.

Smith, J. G., McKee, E. H., Tatlock, D. B., and Marvin, R. F., 1971, Mesozoic granitic rocks in northwest Nevada: A link between the Sierra Nevada and Idaho batholiths: Geological Society of America Bulletin, v. 82, p. 2933-2944.

Snee, L. W., Lund, K., Sutter, J. F., Balcer, D. E., and Evans, K. V., 1995, An ${ }^{40} \mathrm{Ar} /{ }^{39} \mathrm{Ar}$ chronicle of the tectonic development of the Salmon River suture zone, western Idaho, in Vallier, T. L., and Brooks, H. C., editors, Geology of the Blue Mountains Region of Oregon, Idaho, and Washington: Petrology and Tectonic Evolution of the Pre-Tertiary Rocks, Blue Mountains Region: United States Geological Survey Professional Paper 1438, p. 359-414.

Snoke, A. W., and Miller, D. M., 1988, Metamorphic and tectonic history of the northeastern Great Basin in Ernst, W. G., editor, Metamorphism and crustal evolution, western coterminous United States, Rubey Volume 7: Englewood Cliffs, New Jersey, Prentice-Hall, p. 606-648.

Speed, R. C., 1977, Island-arc and other paleogeographic terranes of Late Paleozoic age in the western Great Basin, in Stewart, J. H., and others, editors, Paleozoic paleogeography of the western U. S.: Society of Economic Paleontologists and Mineralogists, Pacific Section, Pacific Coast Paleogeography Symposium 1, p. $349-362$.

— 1978, Paleogeographic and plate tectonic evolution of the early Mesozoic marine province of the western Great Basin, in Howell, D. G., and McDougall, K. A., editors, Mesozoic paleogeography of the western United States: Society of Economic Paleontologists and Mineralogists, Pacific Section, Pacific Coast Paleogeography Symposium 2 , p. 253-270.

— 1979, Collided Paleozoic microplate in the western U. S.: Journal of Geology, v. 87, p. 279-292.

Strayer, L. M. IV, Hyndman, D. W., Sears, J. W., and Myers, P. E., 1989, Direction and shear sense during suturing of the Seven Devils-Wallowa terrane against North America in western Idaho: Geology, v. 17, p. 1025-1028.

Taubeneck, W. H., 1971, Idaho batholith and its southern extension: Geological Society of America Bulletin, v. 82 , p. $1899-1928$.

Thiesse, M.F., ms, 1988, Geology of Paleozoic basinal rocks in the northern Fox Range, Washoe County, Nevada: M.S. thesis; University of Nevada, Reno, 89 p.

Thiesse, M. F., and Wardlaw, B. R., 1985, Structure, metamorphism, and age of Paleozoic basinal rocks in western Nevada: Geological Society of America Abstracts with Programs, v. 17, p. 412-413.

Tikoff, B., Gillaspy, J., Manduca, C., McClelland, W. C., and Markley, M. J., 2000, Lithospheric 'scars': Mantle reactivation in the Salmon River suture zone, Idaho: Geological Society of America Abstracts with Programs, v. 32, no. 7, p. A-107.

Tikoff, B., and Greene, D., 1997, Stretching lineations in transpressional shear zones: an example from the Sierra Nevada Batholith, California: Journal of Structural Geology, v. 19, p. 29-39.

Tikoff, B., and de Saint Blanquat, M., 1997, Transpressional shearing and strike-slip partitioning in the Late Cretaceous Sierra Nevada magmatic arc, California: Tectonics, v. 16, p. 442-459.

Tikoff, B., and Teyssier, C., 1992, Crustal-scale, en echelon "P-shear" tensional bridges: A possible solution to the batholithic room problem: Geology, v. 20, p. 927-930.

Tobisch, O. T., Paterson, S. R., Saleeby, J. B., Geary, E. E., 1989, Nature and timing of deformation in the Foothills terrane, central Sierra Nevada, California: Its bearing on orogenesis: Geological Society of America Bulletin, v. 101, p. 401-413.

Tosdal, R. M., Haxel, G. B., and Wright, J. E., 1989, Jurassic geology of the Sonoran Desert region, southern Arizona, southeastern California, and northernmost Sonora, in Jenney, J. P., and Reynolds, S. J., editors, Geologic evolution of Arizona: Tuscon, Arizona Geological Society Digest 17, p. 397-434.

Umhoefer, P. J., and Schriarizza, P, 1996, Latest Cretaceous to early Tertiary dextral strike-slip faulting on the southeastern Yalakom fault system, southeastern Coast Belt, British Columbia: Geological Society of America Bulletin, v. 108, p. 768-785.

Vallier, T. L., 1995, Petrology of pre-Tertiary igneous rocks in the Blue Mountains region of Oregon, Idaho, and Washington: Implications for the geologic evolution of a complex island arc, in Vallier, T. L., and Brooks, H. C., editors, Geology of the Blue Mountains Region of Oregon, Idaho, and Washington: Petrology and Tectonic Evolution of Pre-Tertiary Rocks of the Blue Mountains Region: United States Geological Survey Professional Paper 1438, p. 125-210.

Verplanck, E. P., and Duncan, R. A., 1987, Temporal variations in plate convergence and eruption rates in the western Cascades, Oregon: Tectonics, v. 6, p. 197-209.

Walker, J. D, Martin, M. W., Bartley, J. M., and Coleman, D. S., 1990, Timing and kinematics of deformation in the Cronese Hills, California, and implications for Mesozoic structure of the southwestern Cordillera: Geology, v. 18, p. 554-557.

Ward, P. D., Hurtado, J. M., Kirschvink, J. L., and Verosub, K. L., 1997, Measurements of the Cretaceous paleolatitude of Vancouver Island: Consistent with the Baja British Columbia hypothesis: Science, v. 277, p. 1642-1645.

Wernicke, B., 1992, Cenozoic extensional tectonics of the United States Cordillera, in Burchfiel, B. C., Lipman, P. W., and Zoback, M. L. editors, The Cordilleran Orogen: Conterminous United States: Boulder, Colorado, Geological Society of America, The Geology of North America, v. G-3, p. 553-582. 
White, D. L., and Vallier, T. L., 1994, Geologic evolution of the Pittsburg Landing area, Snake River canyon, Oregon and Idaho, in Vallier, T.L., and Brooks, H.C., editors, Geology of the Blue Mountains Region of Oregon, Idaho, and Washington: Stratigraphy, physiography, and mineral resources of the Blue Mountains region: United States Geological Survey Professional Paper 1439, p. 55-74.

Willden, R., 1964, Geology and mineral deposits of Humboldt County, Nevada: Nevada Bureau of Mines Bulletin, v. 59, 154 pp.

Wolak, C., and Wyld, S. J., 2000, Mesozoic structure and stratigraphy of the Pueblo Mtns., SE Oregon; Record of an allochthonous terrane in the United States Cordillera: Geological Society of America Abstracts with Programs, v. 32, no. 6, p. A-76.

Wright, J. E., and Fahan, M. R., 1988, An expanded view of Jurassic orogenesis in the western United States Cordillera: Middle Jurassic (pre-Nevadan) regional metamorphism and thrust faulting within an active arc environment, Klamath Mountains, California: Geological Society of America Bulletin, v. 100, p. $859-876$.

Wright, J. E., and Wyld, S. J., 1994, The Rattlesnake Creek terrane, Klamath Mountains, California: An early Mesozoic volcanic arc and its basement of tectonically disrupted oceanic crust: Geological Society of America Bulletin, v. 106, p. 1033-1056.

Wyld, S. J., 1990, Paleozoic and Mesozoic rocks of the Pine Forest Range, northwest Nevada, and their relation to volcanic arc assemblages of the western U. S. Cordillera, in Harwood, D. S. and Miller, M. M., editors, Late Paleozoic and early Mesozoic paleogeographic relations: Klamath Mountains, Sierra Nevada, and related rocks: Geological Society of America Special Paper 255, p. 219-237.

ms, 1992, Geology and geochronology of the Pine Forest Range, northwest Nevada: Stratigraphic, structural and magmatic history, and regional implications: Ph. D. thesis, Stanford University, Stanford, California, 429 p.

1996, Early Jurassic deformation in the Pine Forest Range, northwest Nevada, and implications for Cordilleran tectonics: Tectonics, v. 15, p. 566-583.

1998, Structural development of the Luning-Fencemaker fold-and-thrust belt: New constraints from northern Nevada: Geological Society of America Abstracts with Programs, v. 30, p. 62.

2000, Triassic evolution of the arc and back-arc of northwest Nevada, and evidence for extensional tectonism, in Soreghan, M. J., and G. E. Gehrels, editors, Paleozoic and Triassic paleogeography and tectonics of western Nevada and northern California: Geological Society of America Special Paper 347, p. 185-208.

Wyld, S.J., Quinn, M.J., and Wright, J.E., 1996, Anomalous(?) Early Jurassic deformation in the western United States Cordillera: Geology, v. 24, p. 1037-1040.

Wyld, S. J., and Wright, J. E., 1993, Mesozoic stratigraphy and structural history of the southern Pine Nut Range, west-central Nevada, in Dunne, G., and McDougall, K., editors, Mesozoic Paleogeography of the western United States-II: Los Angeles, California, Society of Economic Paleontologists and Mineralogists, Pacific Section, Book 71, p. 289-306.

1997, Triassic-Jurassic tectonism and magmatism in the Mesozoic continental arc of Nevada: Classic relations and new developments, in Link, P. K., and Kowallis, B. J., editors, Proterozoic to Recent Stratigraphy, Tectonics, and Volcanology, Utah, Nevada, Southern Idaho and Central Mexico: Geological Society of America Field Trip Guide Book, Brigham Young University Geology Studies Vol. 42, Part 1, p.197-224.

2000a, Timing of deformation in the Mesozoic Luning-Fencemaker fold-thrust belt, Nevada: Geological Society of America Abstracts with Programs, v. 32, no. 7, p. A169-A170.

2000b, Major tectonomagmatic events in the Mesozoic U.S. Cordillera and implications for plate interactions: Geological Society of America Abstracts with Programs, v. 32, no. 7, p. A46.

Wynne, P. J., Irving, E., Maxson, J. A., and Kleinspehn, K. L., 1995, Paleomagnetism of the Upper Cretaceous strata of Mounta Tatlow: Evidence for $3000 \mathrm{~km}$ of northward displacement of the eastern Coast Belt, British Columbia: Journal of Geophysical Research, v. 100, p. 6073-6091. 